\title{
Regulatory Fictions: On Marriage and Countermarriage
}

\author{
Elizabeth F. Emens*
}

\begin{abstract}
Debates about marriage currently capture much public attention. Scholars have pushed beyond the question of whether gays are worthy of marriage to ask whether marriage is worthy of gays. The present moment of questioning marriage in its current form may be brief. Thus, we should take this opportunity to imagine the widest possible range of alternatives to our current marriage regime-what I call countermarriage regimes. This Essay draws on two unlikely sources of legal innovation to expand our thinking about marriage alternatives: literature and anti-gay law. Literature offers an array of countermarriage regimes, including exploding marriage, threestrikes marriage, line marriage, renewable marriage, and exculpatory marriage. Anti-gay law, if we reimagine it as applying to everyone, prompts us to consider a world without marriage or indeed without any contracts between intimate partners. In addition to opening our minds to countermarriage possibilities, this Essay shows some overlooked affinities between law and literature, in particular how both law and literature may serve as unlikely sources of regulatory innovation.
\end{abstract}

Copyright $(\mathcal{O} 2011$ California Law Review, Inc. California Law Review, Inc. (CLR) is a California nonprofit corporation. CLR and the authors are solely responsible for the content of their publications.

* Professor of Law, Columbia Law School. Many thanks to the following for relevant conversations and for comments on earlier drafts: Kerry Abrams, Noa Ben-Asher, Mary Anne Case, Ariela Dubler, Robert Ferguson, Adam Fried, Suzanne Goldberg, Jean Howard, Heather James, Amy Kapczynski, Sarah Lawsky, Kevin Maillard, Bernadette Meyler, Martha Nussbaum, Elizabeth Scott, Rachel Smith, Richard Squire, Clay Stockton, Susan Sturm, and participants in the Shakespeare and the Law Conference at the University of Chicago Law School, the Columbia Law School 10-10 Workshop, the New York City-area Family Law Workshop, and the seminar on Marriage in Law, Culture and the Imagination at the University of Virginia School of Law. For their excellent editorial work, I thank the staff of the California Law Review, and for their terrific research assistance, I thank Michelle Hull, Martie Kutscher, Brian Ward, and Beth Williams. 


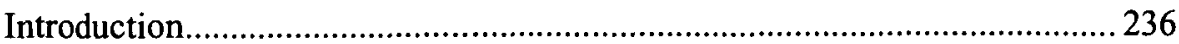

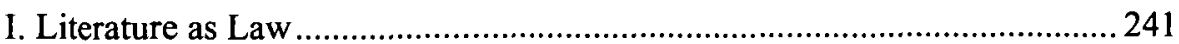

A. Exploding Marriage and Three-Strikes Marriage: Playing with

Permanence ............................................................................... 241

B. Line Marriage: Reconceiving the Basic Structure ...........................245

C. Who Can Enter: Flipping the Presumptions ……………………........247

D. Renewable Marriage: Buying an Option ...........................................248

E. Solitary Marriage: Isolating and Self-Marriage ................................252

F. Exculpatory Marriage: The Ultimate Benefit....................................254

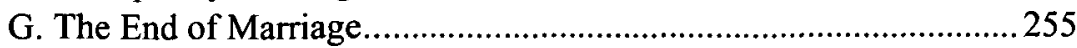

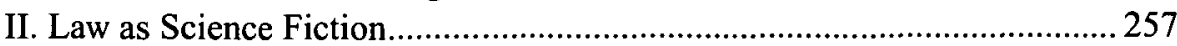

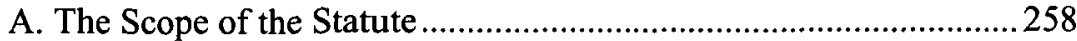

B. Freedom for All: Applying a Broad Reading Broadly ......................263

C. Obligations for All: Conduct over Consent ....................................... 266

D. A Range of Alternatives: From Consent to Conduct and Back ......268

Conclusion: Of Law, Literature, and Innovation ............................................ 269

\section{INTRODUCTION}

The debates in the public sphere over the future of marriage have spurred theoretical debates in the academy over the value of marriage. Even as some scholars debate whether gay people's relationships are worthy of marriagesometimes before large crowds hosted by student organizations-arguably the most robust theoretical debates have occurred among academics who all fall on the pro-gay side of the political spectrum. ${ }^{1}$ Specifically, pro-gay scholars have engaged in heated exchanges over whether marriage should be the political goal of LGBT and leftist thinkers. Some of these scholars want to imagine intimate possibilities apart from marriage, while others think marriage is the most practical way to organize our intimate lives. ${ }^{2}$ And several scholars have

1. Indeed, these theoretical debates are so extensive that this brief Essay will make no attempt to catalogue the relevant work; the texts cited herein are merely exemplary. On terminology in the Essay, note that by "pro-gay" and "anti-gay," I mean something like Janet Halley's definitions. See Janet E. Halley, Sexual Orientation and the Politics of Biology: A Critique of the Argument from Immutability, 46 STAN. L. REv. 503, 516 (1994) ("By anti-gay, I mean to describe those who believe that homosexuality is bad or harmful and should be punished, hidden, or restrained; by pro-gay, I refer to those who believe that homosexuality is good or value neutral and should be celebrated or tolerated."). I would revise these definitions, for instance, by replacing "tolerated" with "included," for reasons well developed in Wendy Brown's intervening critique of "tolerance." See Wendy Brown, Regulating Aversion: Tolerance in the Age of IDENTITY AND EMPIRE (2008). In addition, when applied to laws rather than persons, these terms refer less to beliefs than to the laws' effects or to the discourse surrounding their passage.

2. Compare, e.g., Martha Albertson Fineman, The Neutered Mother, the Sexual Family, and Other Twentieth Century Tragedies (1995) (arguing for vertical parent-child dyads to replace horizontal intimate dyads as the privileged state relationship, and replacing marriage with contractual arrangements), and MichaEL WARNER, THE Trouble WITH Normal: Sex, Politics, And The Ethics of Queer Life (1999) (arguing against the push to same-sex 
identified the current period as a rare window for imagining a space beyond marriage - a space where intimate relationships previously deemed illegal are not yet fully embraced by the long regulatory arm of marriage. ${ }^{3}$

Those who question marriage ask: If marriage urges us to organize our lives in certain conventional ways, then what might society look like in its absence ${ }^{4}$ For some of these scholars, a world beyond marriage sounds hopeful, expansive, or at least interesting for its possibilities. This hypothetical world without marriage stands in sharp contrast to the dim, painful, dignity-deprived world that is typically represented-strategically, but no doubt truthfully, for many-by the plaintiffs' briefs in the same-sex marriage cases. ${ }^{5}$ In a sense, then, for the pro-gay scholars who seek to look beyond marriage, the argument is not over whether gay people are worthy of marriage but, rather, whether marriage is worthy of gay people - and thus of everyone. ${ }^{6}$

This Essay imagines a world beyond our current marriage regime by looking to some unusual sources: fiction and anti-gay law. ${ }^{7}$ Literature seems the obvious place to look when we are trying to imagine new possibilities, but we rarely look to literature as a source for new laws, and we rarely think of law as a prime site of the imagination. Yet fiction and anti-gay law both occupy places beyond our usual regulatory imaginings, places of fantasy and fear. These sources stand outside of-in excess of--our generally applicable laws. ${ }^{8}$

marriage as a normalizing and exclusive endeavor), and Mary Lyndon Shanley, Afterword, in Just MARRIAGe 109 (Joshua Cohen \& Deborah Chasman eds., 2004) (drawing on essays in this volume by Cossman, Fineman, Metz, and Brown to conclude that the state should not sponsor marriage per se but should offer only civil unions), with Carol Sanger, A Case for Civil Marriage, 27 CARDozo L. REv. 1311 (2006) (expressing skepticism about the ability of a contract law regime to adequately replace marriage law), and Elizabeth $\mathrm{S}$. Scott, A World Without Marriage, 41 FAM. L.Q. 537, 539, 565-66 (2007) (concluding that, while the choice between expanding marriage and replacing it with universal civil unions is a "difficult one," expanding marriage is probably the better choice), and Mary Lyndon Shanley, Just Marriage: On the Public Importance of Private Union, in JUST MARRIAGE, supra, at 3 (arguing that marriage should be reformed rather than replaced with a contractarian regime).

3. See, e.g., Katherine M. Franke, Longing for Loving, 76 FordHaM L. REV. 2685 (2008); Elizabeth F. Emens, Monogamy's Law: Compulsory Monogamy and Polyamorous Existence, 29 N.Y.U. Rev. L. \& Soc. Change 277 (2004).

4. See, e.g., Patricia A. Cain, Imagine There's No Marriage, 16 QuinniPIAC L. REv. 27 (1996); sources cited supra note 2.

5. See, e.g., Final Reply Brief of Plaintiffs-Appellees at 23, Vamum v. Brien, 763 N.W.2d 862 (lowa 2008) (No. 07-1499), 2008 WL 5156764 at *23 ("It is an undisputed fact that [plaintiffs'] inability to marry their chosen partners is a painful frustration of their life goals and dreams, their personal happiness and their self-determination.") (internal quotation marks omitted); see also Transcript of Oral Argument at 21, Vamum v. Brien, 763 N.W.2d 862 (Iowa 2008) (No. 07-1499) (plaintiffs' counsel arguing that refusal to extend marriage to same-sex couples shows "lack of respect and dignity and equality"); Seth Hemmelgarn, Kids Feel the Impact of Prop 8, BAY AREA REP., Mar. 5, 2009, available at http://ebar.com/news/article. php?sec $=$ news \&article $=3770$.

6. Cf., e.g., Shanley, Afterword, supra note 2.

7. For an explanation of the term "anti-gay," see supra note 1 .

8. Cf. Adam Phillips, ON Balance 2, 9 (2010) ("When people are being extreme they push things to their limits; when they are being excessive they push things beyond their limits. . . 
This use of fiction and anti-gay law to imagine new legal regimes adds to the tools of law and literature as a discipline. 'Law and literature generally comprises categories such as "law in literature" (think trials in Dickens), "law as literature" (think deconstructive critique of legal opinions), and "law of literature" (think copyright law). ${ }^{10}$ In contrast, by looking to fiction for ideas for new laws, this Essay engages in an enterprise we might call "literature as law." This category bears some relation to the category of law in literature, but, as I explain below, the aim here is not to study how law operates in literature -indeed, most of my examples aren't even real legal regimes within their fictional worlds-but rather to draw from literature inspiration for novel laws. ${ }^{11}$

In addition, considering anti-gay laws as a template for legal regimes evokes the genre of science fiction, in that one strand of science fiction involves dystopian (or utopian) societies with broadly restricted (or expanded) individual liberties. ${ }^{12}$ Thus, the project here of taking laws that specifically

[S]omething as powerful as excess might-if we can suspend our fear-allow us to have thoughts we have never had before.").

9. Cf. Robin L. West, The Literary Lawyer, 27 PAC. L.J. 1187, 1187 (1996) ('Surely by this point-twenty some years into this renaissance [of 'interest in the various connections between the fields of "law" and "literature"']-it now makes some sense to speak of the "law and literature' movement as a recognizable discipline, or sub-specialty, within both the literature and legal academies.").

10. See, e.g., Robert Weisberg, The Law-Literature Enterprise, 1 Yale J.L. \& Human. 1, 1 (1988) (defining "law-in-literature" as "involv[ing] the appearance of legal themes or the depiction of legal actors or processes in fiction or drama" and "law-as-literature" as "involv[ing] the parsing of such legal texts as statutes, constitutions, judicial opinions, and certain classic scholarly treatises as if they were literary works"); Kenji Yoshino, The City and the Poet, 114 YALE L.J. 1835, 1838 (2005) (noting that Weisberg's two prongs leave out "law-of-literature" which covers "[t]he legal regulation of literature through obscenity, defamation, and copyright regimes"); see also Jack M. Balkin \& Sanford Levinson, Law and the Humanities: An Uneasy Relationship, 18 YaLE J.L. \& Human. 155, 182-84 (2006) (noting Weisberg's categories).

11. Others have used the phrase "literature as law," though, to my knowledge, differently. See, e.g., Cynthia G. Hawkins-León, "Literature as Law": The History of the Insanity Plea \& a Fictional Application Within the Law \& Literature Canon, 72 Temp. L. Rev. 381, 385 (1999) ("review[ing] a particular work of fiction as though it were an actual case file and hypothesiz[ing] the possible outcome(s) of an imaginary criminal trial"); Desmond Manderson, From Hunger to Love: Myths of the Source, Interpretation, and Constitution of Law in Children's Literature, 15 LAW \& Literature 87, 127 (2003) (discussing Maurice Sendak's Where the Wild Things Are as a "story [that] helps form and develop the mental attitudes to law of the children who read it. It does not just illustrate but inaugurates legal subjectivity. It is law as literature and literature as law, which is to say, myth . ..."); Robin L. West, Literature, Culture, and Law - at Duke University, in Options for Teaching Literature and Law (Austin Sarat et al. eds.) (forthcoming), available at http://papers.ssm.com/sol3/papers.cfm?abstract_id=1201867 (comparing the "'literature as law" view attributed by [Robert] Ferguson to the Jeffersonian man of letters," with Naomi Mezey's "culture as law" view, both of which see legal sources as part of a "seamless web of authority with the culture that constitutes it," though through "high" and "low" cultural sources, respectively).

12. While recognizing that the distinction between utopian and dystopian fiction depends in part on one's subjective ideals, and that the definition of science fiction is contested, we can nonetheless loosely identify examples of science fiction dystopias, including MarGareT Atwood, The Handmaid's Tale (1985); Philip K. Dick, The Minority Report (1956); Kurt VonNegut, Welcome to the Monkey House (1973), and examples of science fiction utopias, 
target a minority of the population and using them to reimagine universal legal regimes might be understood as a kind of "law as science fiction.",13

These unusual inquiries yield a variety of intriguing countermarriage possibilities. By countermarriage, I mean the vast range of alternative ways we might regulate intimate relationships, from tweaks of existing marriage law (for instance, assuming marriages automatically expire after a term of years), to wholesale replacement of marriage with some other regime (for instance, obligations that attach based on behavior rather than consent). ${ }^{14}$

I invite the reader into this exploration of countermarriage possibilities for reasons both general and specific. Generally, this Essay is an exercise in innovative thinking. Recent work in behavioral science has shown how much our decisions are determined by the frames surrounding them. ${ }^{15}$ Thinking along unusual pathways may help free us from our assumptions so that we may view the status quo with fresh eyes. Inventing and considering alternatives to current practice may benefit both our descriptive and our normative analyses across areas of law. In addition, exploring different types of sources for legal thinking, such as literature or apparently conservative laws, may give us new tools for innovation-a topic I revisit in the Conclusion.

More specifically, this Essay urges the reader to think innovatively about marriage. The fanciful exercises presented here thus complement the thoughtful work already underway on this subject. As noted above, debating the merits of marriage as a regulatory apparatus has occupied numerous scholars in recent years. ${ }^{16}$ In light of the academic and popular interest in considering marriage's aims, functions, and value to society, this seems a critical moment for sharpening and expanding our thinking in this area. There is work to be done,

including Charlotte Perkins Gilman, Herland (1915); and Robert Heinlein, Stranger in a Strange Land (1961).

13. As a form of critique, scholars sometimes compare draconian legal and other institutional regimes to science fiction. See, e.g., Daphne Patai, There Ought to Be a Law, 22 WM. Mitchell L. Rev. 491 (1996). Viewing an existing legal regime as like science fiction could also be called "law as science fiction." This Essay is unusual, however, in taking a restrictive legal regime as the starting point for reimagining our broader legal regime. In a sense, then, the technique in this Essay might be more precisely called "law as science fiction as law," but that terminology would be dystopic for aesthetic reasons.

14. I focus principally on sexually intimate relationships here. For thoughtful critiques of the legal centrality of intimacy so defined, see, for example, Brenda Cossman, Beyond Marriage, in JUST MARRIage 93, supra note 2; Laura A. Rosenbury \& Jennifer E. Rothman, Beyond Intimacy 2 (Sept. 8, 2008) (unpublished manuscript) (on file with author).

15. For foundational work in this field, see Amos Tversky \& Daniel Kahneman, The Framing of Decisions and the Psychology of Choice, 211 ScI. 453 (1981). For discussion of this field of study in legal contexts, see, for example, Ian Ayres, Menus Matter, 73 U. CHI. L. REv. 3 (2006); Colin Camerer et al., Regulation for Conservatives: Behavioral Economics and the Case for "Asymmetric Paternalism", 151 U. PA. L. REv. 1211 (2003); Cass R. Sunstein \& Richard H. Thaler, Libertarian Paternalism Is Not an Oxymoron, 70 U. CHI. L. REv. 1159 (2003).

16. See, e.g., sources cited supra notes 1-4 and infra notes 93-96; Mary Anne Case, Marriage Licenses, 2004 Lockhart Lecture, 89 MiNN. L. REv. 1758, 1792-97 (2005); Elizabeth S. Scott \& Robert E. Scott, Marriage as Relational Contract, 84 VA. L. REv. 1225 (1998). 
and we want to be sure we are up to the task.

Of course, we may continue to accept marriage in its current form even after we question our assumptions about it. Considering alternatives to an institution may lead us to embrace a different approach, or, on the contrary, such a process may lead us to conclude that the institution has value, perhaps with greater confidence than if we had remained tied to our assumptions. ${ }^{17}$ This Essay offers an array of inventive variations on our current marriage regime to help free our minds for that evaluative process in the rest of our public and scholarly discourse. If this moment between gay decriminalization and legal domestication is already closing - and I am increasingly hopeful that it is - then we should seize this opportunity to look in any remaining directions for new ideas and possibilities. We should make the most of this window before it closes.

Lastly, but not trivially, I hope this experience of engaging the imagination, of entertaining visions of a world slightly or wildly different from our own, will be pleasurable. Pleasures vary, of course, and this endeavor will not be everyone's idea of fun. Though the hedonic aim of the Essay is not insignificant to the author, for those readers whose tastes differ I hope the other aims will be sustaining.

Following this Introduction, Part I of the Essay draws on fictional sources to canvass some unusual visions of what marriage might be. These include exploding marriage, three-strikes marriage, line marriage, renewable marriage, self-marriage, and exculpatory marriage. Part II looks to another unlikely source for imagining countermarriage possibilities for all: anti-gay laws, in the form of state Defense of Marriage Acts ("mini-DOMAs"). In particular, this Part considers a law passed in Virginia in 2004 that expressly forbids "partnership contract[s] or other arrangement[s]" between "persons of the same sex" that "purport[] to bestow the privileges or obligations of marriage." 18 This Part reconceives and extends this restriction, imagining what it might mean instead to disallow not only marriage but also all contracts for all intimate partners. After reflecting on these diverse sources, in the Conclusion I offer some observations on the contributions that literature may make to the project of legal innovation.

Before beginning, I offer a caveat for the normatively inclined reader: this Essay explores but does not prescribe. Though discussions of marriage are typically normative, this Essay resists drawing normative conclusions about whether we should have marriage and in what form. The aim here is instead to step away from this prescriptive project and generate a broad range of

17. Cf. Phillips, supra note 8 , at 10 ("Perhaps as part of growing up we need to be excessive- to try to break all the rules just to be able to find out what, if anything, the rules are made of, and why they matter. Perhaps only the road of excess can teach us when enough is enough.").

18. VA. CODE ANN. $\S 20-45.3$ (2004). 
countermarriage regimes inspired by unlikely sources.

I.

\section{LITERATURE AS LAW}

Literature can open up imaginative possibilities. Because it need not comply with existing laws and social conventions, literature can unsettle our usual frame of reference and invite us to consider new worlds. Thus, literature offers a relatively untapped resource for imagining novel legal regimes. ${ }^{19}$ Building on the typology of "law and literature" categories noted above, we can think of this endeavor as "literature as law." law possibilities by examining a series of fictional texts that suggest alternative frameworks to our current marriage law: in other words, countermarriage regimes. Some of the regimes presented here are set out wholesale in the relevant literary text; others are extrapolations of an arrangement embedded in the text. I thus present a selection of fictional possibilities that I hope will be provocative and perhaps even delightful for their distance from the regimes we generally consider in our debates over marriage.

\section{A. Exploding Marriage and Three-Strikes Marriage: Playing with Permanence}

Goethe's novel Elective Affinities ${ }^{21}$ entertains two different countermarriage regimes that play with the permanence of marriage. A core aspiration of marriage is that it last forever: Till death do us part. The reality is of course rather different, with divorce rates for first marriages at 45-50 percent in the United States. ${ }^{22}$ And while marriage rates have declined, spouses continue to enter their marriages optimistic about their prospects for staying together, as reflected in their reluctance to sign prenuptial agreements. ${ }^{23}$

19. No pun on "novel" is intended here, but it is interesting to note that the term novel meant, in one historical context, new laws. The fifth definition of novel in the Oxford English Dictionary is "Roman Law. A new decree or constitution, supplementary to a codex; esp. any of those enacted by the emperor Justinian. Now hist." See Oxford English Dictionary Online: novel, http://www.oed.com/view/Entry/128757?rskey=eTSpZN\&result=1\&isAdvanced=false\# (last visited Mar. 1, 2011) (quoting Gibbon, inter alia, as here: "1788 Gibbon Decline \& Fall IV. xliv. 366 The nine collations, the legal standard of modern tribunals, consist of ninety-eight Novels").

20. See supra note 10 and accompanying text.

21. Johann Wolfgang von Goethe, Elective Affinities, in 11 GoeTHE: The ColleCted Works 89 (David E. Wellbery ed., Judith Ryan trans., Princeton University Press 1995) (1809).

22. Linda A. Jacobsen \& Mark Mather, U.S. Economic and Social Trends Since 2000, 65 Pop. Bull., 10 (Feb. 2010).

23. See, e.g., Heather Mahar, Why Are There So Few Prenuptial Agreements? 1 (Harvard Law Sch. John M. Olin Center for Law, Econ. \& Bus. Discussion Paper Series 2003), available at $\mathrm{http}: / /$ sr.nellco.org/cgi/viewcontent.cgi?article=1224\&context=harvard_olin (estimating that only 5-10 percent of couples sign prenuptial agreements). On U.S. marriage rates, see D'Vera Cohn, The States of Marriage and Divorce, Pew Research Center Social \& Demographic Trends (October 15, 2009), http://pewsocialtrends.org/pubs/746/states-of-marriage-and-divorce ("The proportion of Americans who are currently married has been diminishing for decades and is lower than it has been in at least half a century.... Among Americans 18 and older, the proportion 
Goethe's countermarriage regimes play with this assumption of permanence.

Goethe's first countermarriage idea is what we might call exploding marriage. In this regime, marriage expires after a fixed term of years. ${ }^{24}$ The character of the Count in Elective Affinities explains to an assembled dinner group that "[o]ne of [his] friends, whose high spirits mostly express themselves in suggestions for new laws, claimed that every marriage should only be contracted for a period of five years." 25 Five years, the friend thought "was a nice odd number, a sacred number, and a period just sufficient to get to know one another, produce a number of children, separate, and, the nicest part of it, become reconciled again." ${ }^{26}$ In explaining his proposal, the friend would "exclaim":

How happily the first years would pass! Two or three years would go by very pleasantly. Then one party, eager to see the relationship continue, would become increasingly attentive the closer the end of the contract approached. The indifferent or even dissatisfied partner would be charmed and won over. They would forget, as we do the hours in good company, that time was passing, and would be most pleasantly surprised to notice, after the deadline was already passed, that the contract had been extended without a word having ever been spoken. $^{27}$

The Count's friend implicitly critiqued the ways married people sometimes come to take each other for granted, and cease to invest in the marriage or to appreciate their spouse. Hence the expiration date. The looming deadline forces the partners to consider each other closely again, much as one might energetically consume-or discard-an overlooked item in the refrigerator upon noticing it expires tomorrow. Interestingly, although the friend's proposal seems to imply that the default rule is for the marriage to explode, not continue, at the five-year mark, ${ }^{28}$ he also seems to suggest that the couple can opt out of that presumption and silently ratify their relationship through the behavior of renewing their enthusiasm for each other and continuing together past the deadline. $^{29}$

currently married, but not separated, is $55 \%$ for men and $50 \%$ for women.").

24. I thank Martha Nussbaum for directing me to this novel after hearing me talk about exploding marriage, a concept I think I first heard mentioned by Amy Kapczynski, to whom thanks are also due.

25. Goethe, supra note 21 , at 139.

26. Id.

27. Id.

28. Default rules are background rules that govern if contracting parties do not contract around them by opting for another rule. See sources cited supra note 15 . For a discussion of the variability of default rules and their possible uses in marriage law, see Elizabeth F. Emens, Changing Name Changing: Framing Rules and the Future of Marital Names, 74 U. CHI. L. REv. 761 (2007).

29. Legal analogues include "year-and-a-day marriages, renewable with the consent of the parties, common among the Irish" and a bill introduced into the Maryland Legislature in 1971 titled "Marriage-Contractual Renewal," which provided "that a marriage be considered a 
The Count offers another marriage alternative, three-strikes marriage. ${ }^{30}$ Here, only marriages involving someone who has been married twice before are legally permanent:

"That same friend," [the Count] went on, "made yet another suggestion for a new law: a marriage should only be regarded as indissoluble when it was the third marriage of one or both. For this was incontrovertible evidence that marriage was something this person could not do without. Now it would also be known how they had behaved in their previous relationships, and whether they had bad habits, which more frequently lead to separations than do bad characters. We should find out about one another; and we should keep an eye on married people as well as unmarried ones, since we could not know what might come to pass."

"That would greatly increase society's interest," said [another character]; "for indeed, when we are married, nobody bothers about our virtues or faults anymore."

The suggestion that marriage should be permanent only if at least one party has been married twice before seems, in a way, perverse. It seems to assume the impermanence of marriage, at least of first (and second) marriages. ${ }^{32}$ And it emphasizes desire for marriage itself-as "something this person could not do

contract for three years with an option to renew for three years, renewable forever, upon mutual consent thereto." See Mary Anne Case, A Brief History of Marriage in Anglo-American Law with Special Reference to those Points of Commonality with the Law of Corporations, 4 n.19 (unpublished manuscript, on file with author) (citing H.D. 623, Feb. 26, 1971). The law recently offered a grimmer, mandatory (rather than default) version of exploding marriage to the same-sex couples married in San Francisco from February 12 to March 11, 2004; later that year, the California Supreme Court declared those marriages void. Lockyer v. San Francisco, 33 Cal. 4th 1055,1120 (2004). And a geographical, rather than chronological, version of this might be extrapolated from the situation of same-sex couples who marry in one of the few states recognizing same-sex marriage, who then move to a state that refuses to give full faith and credit to their marriage (as announced by many of the state mini-DOMAs, see infra Part II). A more voluntary (and playful) version of this hardship could be reimagined as a same-sex couple's traveling state to state on their honeymoon, watching their marriage disappear and reappear. (I thank Suzanne Goldberg for this point.) For those who thought sex was sexier before it was legal, this kind of vacillating marriage might have a certain appeal. See Bernard E. Harcourt, Supreme Court Review, Foreword: "You Are Entering a Gay and Lesbian-Free Zone": On the Radical Dissents of Justice Scalia and Other (Post-) Queers, 94 J. CRIM. L. \& CRIMINOLOGY 503, 527 (2004) (quoting Sarah Schulman).

30. Third-time's-the-charm marriage might be a warmer name for this one, though harder to say than three-strikes marriage, which also captures the sense in which this regime takes one out of the dating game after the third "swing."

31. Goethe, supra note 21 , at 140 .

32. A few states have enacted laws that play with the permanence dimension of marriage in a different way: covenant marriage statutes make entry and exit more difficult for those who opt into them (which is apparently a very small group). See ARIZ. REv. STAT. ANN. \$§ 25-901 to -906 (2010); Ark. Code ANN. \$§ 9-11-801 to -810 (2010); LA. Rev. STAT. ANN. \$§ 9:272-274, 9:307 (2009); Steven L. Nock et al., Covenant Marriage Turns Five Years Old, 10 MicH. J. GENDER \& L. 169, 170 (2003) (estimating that "less than two percent of all newly contracted marriages in Louisiana are covenant marriages”). 
without" - rather than for the individual partner. And where the Count does attend to the individual, he focuses on habits rather than character. Such an account is surprising because a lover is typically expected to adore the essence of the person. Habit seems superficial, relative to character, though a long tradition of writers has argued otherwise. ${ }^{33}$

Both of these countermarriage possibilities resist the usual sentimentality that presumes some people are meant for each other or even that the heart of marriage is necessarily love. On the other hand, the two alternatives may be read to push in opposite directions, with three-strikes marriage focused on a party's reaffirming their commitment to the institution time and time again, and exploding marriage focused on the parties' reaffirming their commitment to each other time and time again. By contrast to three-strikes marriage, exploding marriage might seem highly romantic in its emphasis on the partners' affirmative desires, rather than on other values. Thus, both of these countermarriage possibilities vary our current regime, with one favoring the institutional over the romantic dimensions of marriage and the other favoring the reverse.

The novel implies that it is dangerous to question the commonplace pieties about love, marriage, and permanence. For instance, one character is quite concerned about exposing a young woman present at the dinner to such irreverent talk about the sacred institution. ${ }^{34}$ Moreover, the source of these marriage variants is a controversial character, someone who has been burned by marriage in its current form. The Count has been unhappily married for years, but unable to get out of his unhappy marriage and marry the woman he loves; he thus spends as much time as he can traveling the country with his beloved, and is a scandalous, as well as dissatisfied, figure. ${ }^{35}$ The text thereby creates some distance from the proposer of countermarriage possibilities by presenting him as bitter and cynical. ${ }^{36}$ And yet Goethe also portrays the questioner of marriage as hopelessly in love, suggesting that his cynicism might be a cover for his deeply romantic nature. Rather than being the most cynical about love and relationships, then, the marriage critic might in fact be the most romantic. This tension-between cynicism and romance, between distance from the alternatives and engagement with them-gives the reader ample space to

33. For one such argument, and for a history of this vein of thinking, see, for instance, Elaine SCaRry, Thinking IN AN EMERGENCy (forthcoming 2011) (on file with author).

34. One of their circle, Charlotte, worries over the practice of talking about "criminal or reprehensible actions as though they were common everyday, or even praiseworthy ones; and certainly everything pertaining to marriages comes into this category." Goethe, supra note 21 , at 140.

35. See id. at 136. Note that even the Count distances himself from the proposals, attributing them to a friend. Id. at 139-40.

36. This image of the questioner of marriage as someone who has been burned, by love or marriage, appears elsewhere in fiction. See, e.g., the discussion of Hamlet, infra note 90, and accompanying text. 
consider the countermarriage proposals, unencumbered by any clear judgment from the text. The reader can make what she will of the proposals and of their various suggestions, taken together, that the institution of marriage may be the true object of love, or that love may be more important than commitment in marriage, and that, in either case, a marriage's structural features may determine its success or failure.

\section{B. Line Marriage: Reconceiving the Basic Structure}

Robert Heinlein's novel The Moon Is a Harsh Mistress ${ }^{37}$ offers us the idea of line marriage. Real-world marriage typically imposes expectations along the dimensions of numerosity (permitting only two persons per marriage) and exclusivity (permitting erotic intimacy only within marriage) ${ }^{38}$ Line marriage necessarily violates the numerosity requirement, and it may also depart from the exclusivity requirement: ${ }^{39}$ in this fanciful marital form, spouses of both sexes are added to the marriage, one by one, over time. Line marriage bears a similarity to what we generally think of as polygamy, except that it is symmetrical and (at least structurally) egalitarian, with multiple spouses of both sexes. ${ }^{40}$ It is a "line" in its continuity over time: adding new spouses one after the other makes it possible that the marriage could continue interminably, like a corporation.

The form is introduced in the novel by a participant who emphatically characterizes it as "nice"-a high compliment in his distinctively clipped way of speaking. ${ }^{41}$ He says,

Our marriage nearly a hundred years old .... -twenty-one links, nine alive today, never a divorce. Oh, it's a madhouse when our descendants and in-laws and kinfolk get together for birthday or

37. Robert A. Heinlein, The Moon Is a Harsh Mistress (Orb ed. 1997) (1966).

38. See Emens, Monogamy's Law, supra note 3, at 308-09.

39. In principle, line marriage could be either exclusive or open, in that the many spouses within a particular line marriage could be permitted sexual intimacy only with one another, or with others outside the marriage as well. As practiced in the novel, spouses apparently permit sexual contact outside the marriage in a freer way than might be expected in a monogamous culture, but such contact is sometimes presented as a violation (however minor or accepted) of some presumed principle of fidelity and sometimes not. Compare, e.g., HeInLEIN, supra note 37, at 114 (describing how the narrator's senior wife housed his new female friend in a room close to his workshop, "where I slept when slept alone," in effect telling him, "plain as print", "Go ahead, dear. Don't tell me if you wish to be mean about it. Sneak behind my back."'), with id. at 279 (explaining with bemusement that a new visitor to their moon culture was worried when the narrator's wife prepared to kiss him vigorously in greeting after a dangerous journey, because the visitor was from Earth where marriage "makes a difference" to such behavior and the visitor therefore foolishly thought the narrator-husband who was standing right there "might take offense!').

40. The novel also contains other forms of multi-party marriage; on the moon, where the novel takes place, the "commonest type" of marriage is a "troika" with two men and a woman (presumably because of the shortage of women). Id. at 134.

41. The narrator generally avoids articles and otherwise abbreviates his speech, almost as one might imagine a computer would speak. 
wedding-more kids than seventeen, of course; we don't count 'em after they marry or I'd have 'children' old enough to be my grandfather. Happy way to live, never much pressure. Take me. Nobody woofs if I stay away a week and don't phone. Welcome when I show up. Line marriages rarely have divorces. How could I do better? ${ }^{42}$

His interlocutor concurs, "I don't think you could.,

Their dialogue further elucidates the variation available within that line structure. The marriage accommodates new spouses at any time because "[s]pacing has no rule, just what suits us." And individual families may create their own patterns, and deviations from those patterns. For example, one family institutes a requirement to alternate the sex of each new spouse, but treats it flexibly: "Been alternation up to latest link, last year. We married a girl when alternation called for boy. But was special." 45 Throughout the book, line marriage repeatedly engenders praise for its personal and societal virtues, including "financial security, fine home life it gives children, fact that death of a spouse, while tragic, could never be tragedy it was in a temporary family, especially for children-children simply could not be orphaned." ${ }^{, 46}$ Such analytic praise is underscored by the emotional context in which it is offeredas in the statement following this list of benefits: "Suppose I waxed too enthusiastic - but my family is most important thing in my life."

Even greater sexual openness characterizes relationships of more than two elsewhere in Heinlein's work. In his best-known novel, Stranger in a Strange Land $^{48}$ the characters organize their intimate relationships on a variety of models, including apparently monogamous pairings. The most significant and best-loved characters, however, revel in a combination of love and sex with a range of devoted partners and friends in a communal setting. ${ }^{49}$

Traditional polygamy, more precisely termed polygyny, in which one man is married to more than one woman, appears elsewhere in fiction and in fact, and has been explored in detail by other sources. ${ }^{50}$ But the line-marriage structure in particular highlights the possibilities for varying marital structure

42. Id. at 42 .

43. Id.

44. Id.

45. Id.

46. Id. at 260. See also id. at $47,172,261-62$. One of the ways that the inhabitants of Earth are rendered unsympathetic is through their oppressive response-namely, criminal charges-to the narrator's line marriage back on the moon. Id. at 262.

47. Id. at 260 .

48. Robert Heinlein, Stranger in a Strange Land (Ace Books 1987) (1961).

49. See id.

50. See, e.g., Sarah Barringer Gordon, The Mormon Question: Polygamy and Constitutional Conflict In Nineteenth-Century America (2002); Raise the Red LANTERN (ERA International et al. 1991); see also Emens, Monogamy's Law, supra note 3, at $314-17,332-34$ (citing sources). 
along a range of dimensions. Within Heinlein's imagined universes, countermarriage possibilities vary the number of partners (numerosity), and the openness of their relationships (exclusivity), in both structured and unstructured ways.

\section{Who Can Enter: Flipping the Presumptions}

In an essay in the Boston Evening Transcript on August 18, 1900, African-American ${ }^{51}$ fiction writer Charles Chesnutt imagined a kind of racial utopia. ${ }^{52} \mathrm{He}$ predicted that "the future American" would be a mixture of the current races, and he hypothesized a legal regime that would speed us to this conclusion:

We will assume ... . that the laws of the whole country were as favorable to ... amalgamation as the laws of most Southern States are at present against it; i.e., that it were made a misdemeanor for two white or two colored persons to marry, so long as it was possible to obtain a mate of the other race-this would be even more favorable than the Southern rule, which makes no such exception. ${ }^{53}$

Even if we erroneously assume two pure races at the start, Chesnutt concluded, "in three generations the pure whites would be entirely eliminated, and there would be no perceptible trace of the blacks left."54

This imagined regulatory regime, akin to one elaborated in slightly different form by legal scholar Geoffrey Stone a century later, ${ }^{55}$ flips the presumption as to who qualifies to enter a marriage. Instead of our historical legal prescription-and ongoing majority social practice-of racially homogamous marriage, ${ }^{56}$ Chesnutt's law (partially) prescribes racially heterogamous marriage.

Various works of science fiction alter other conventional expectations of entrants into marriage, such as the widely held presumption of adult age (by

51. Chesnutt considered himself African-American, as did the one-drop laws of various jurisdictions, though his paternal grandfather was a white slave owner and he could apparently pass for white (though he chose not to do so). See, e.g., Pauline Carrington Bouvé, An Aboriginal Author, Boston Evening Transcript, Aug. 23, 1899, at 16; David Perlmutt, Stamp Honors Black Author with N.C. Roots, News \& OBSERVER (Raleigh, N.C.), Oct. 7, 2007, at B3.

52. Charles W. Chesnutt, The Future American, Boston Evening Transcript, Aug. 18, 1900, available at http://www.online-literature.com/charles-chesnutt/wife-of-his-youth/11/. I thank Kevin Maillard for calling my attention to this text.

53. Id.

54. Id.

55. See Geoffrey R. Stone, Commentary, If America Only Had One Mixed Race, CHI. Trib., Mar. 30, 1999, at 17 (reprinting Stone's University of Chicago Centennial Contribution) (setting out a thought experiment, the Mandatory Miscegenation Act of 2100 , which provided that "[n]o person who is not genetically certified as a person of mixed race may procreate with another person of the same race") (internal quotation marks omitted).

56. Homogamy refers to pairing within one's own type. For further discussion, see Elizabeth F. Emens, Intimate Discrimination: The State's Role in the Accidents of Sex and Love, 122 HARV. L. REV. 1307 (2009). 
making the threshold younger out of necessity in a society decimated by plague $^{57}$ ), or about the sex of the participants (by encouraging, for instance, same-sex relations to stem population growth in a society facing resource depletion ${ }^{58}$ ). Unlike the science fiction variations on this theme, which tend to present new presumptions about who should enter marriage in functional terms, Chesnutt and Stone offer political justifications. In both cases, the fictional nature of the work provides an opportunity for variations that challenge assumptions about the entrants to marriage.

Moreover, Chesnutt's version of this altered reality invokes the criminal law, making certain kinds of marriages misdemeanors. This is a strong form of prohibition. Compared with the softer version of a rule presented in Goethe's exploding marriage, Chesnutt's criminal prohibition highlights the ways the form of the rule can vary-from criminal prohibition of one sort or another, to civil fines, to regulatory approval, to default rules (creating a presumption, which parties can overcome by speaking to the contrary), to forced choosing (requiring parties to choose an option, either of their own design or off a menu), to framing rules (framing parties' decisions with particular words or context). A rich literature on default rules explores the different ways that choices can be framed-with some of that work specifically applying these tools to the realm of family law. ${ }^{59}$ The Chesnutt essay, though far from inventing these sorts of variations, calls our attention to degrees of regulatory strength through its invocation of the harshest state regime, criminal prohibition.

\section{Renewable Marriage: Buying an Option}

Shakespeare's The Winter's Tale ${ }^{60}$ provides the inspiration for a form of countermarriage that, generalized, we might call renewable marriage (or perhaps, more playfully, take-a-break-from-marriage marriage ${ }^{61}$ ). This countermarriage form plays with the permanence, not of the marriage commitment, but of its termination. Extrapolating from The Winter's Tale, we can imagine marriage as a renewable resource: mistreatment by one spouse of the other leads to a term of years apart, which, if it leads to remorse, can end with vibrant reunion.

King Leontes, thinking his wife Hermione unfaithful with his friend, and desperately jealous, jails her, holds a trial in which he disregards the oracle that declares her innocent, and then orders the murder of their newborn daughter, Perdita (though she is secretly hidden rather than killed). His actions lead to the

57. See George Stewart, Earth Abides (1949). I thank Alan Fried for pointing me to Stewart and to Haldeman. See infra note 58.

58. See Joe Haldeman, The Forever War (1974).

59. See, e.g., Ayres, supra note 15; Camerer et al., supra note 15; Emens, Changing Name Changing, supra note 28; Sunstein \& Thaler, supra note 15.

60. William Shakespeare, The Winter's Tale (J.H.P. Pafford ed., Arden 2006).

61. With acknowledgements to Janet Halley's Split Decisions: How and Why To TAKE A BREAK FROM FEMINISM (2008). 
death of their fragile son and the eventual proclamation of Hermione's death from grief as well. After sixteen years pass, Perdita is recovered, and Hermione's friend Paulina elicits from the remorseful King both an admission that he effectively killed his wife through his cruelty and a promise that he would never marry again. The King and Perdita come, with other assembled guests, to ask Paulina to show them a statue of the Queen in her possession. Paulina presents the statue to the visitors, and as they admire the likeness, Paulina promises to bring the Queen back to life: "It is requir'd/You do awake your faith. Then all stand still: / Or-those that think it is unlawful business / I am about, let them depart." ${ }^{, 62}$ The King orders Paulina to proceed:

Paul[ina]:

Music, awake her; strike! [Music.]

'Tis time; descend; be stone no more ...

Bequeath to death your numnesse; for from him

Dear life redeemes you. You perceive she stirs:

[Hermione comes down.]

Start not: her actions shall be holy as

You hear my spell is lawful. [To Leontes.] Do not shun her,

Until you see her die again; for then

You kill her double: Nay, present your hand:

When she was young you woo'd her; now, in age,

Is she become the suitor?

Leontes:

Oh, she's warme!

If this be magic, let it be an art

Lawful as eating. ${ }^{63}$

The play offers language at various points to suggest that Hermione has been in hiding all these years, cared for by Paulina, but it also leaves open the possibility that her statue has truly been brought to life. ${ }^{64}$

Unlike some of our other fictions, which explicitly offer countermarriage regimes, The Winter's Tale offers merely a scenario, an anecdote, of renewable marriage played out between these lovers. The closest we might come to an affirmative regulatory vision comes in the possible element of magic in the

62. ShAKESPEARE, supra note 60, at 158 (V.iii.94-97).

63. Id. at 159 (V.iii.98-111).

64. Much language pushes toward, but does not definitely determine, the reading of Hermione as having been hidden rather than conjured. For instance, Leontes notes how her statue has wrinkles she did not have sixteen years before-which Paulina explains as part of the sculptor's talent in rendering her as she would be now. Id. at 155 (V.iii.27-32). The text further tells us that Paulina has been visiting a remote place, possibly Hermione's hiding place-_- "for she hath privately twice or thrice a day, ever since the death of Hermione, visited that removed house"--perhaps to care for her. Id. at 151 (V.ii.105-7). 
play: the suggestion that magic might assist the Queen's return hints at the possibility of an approving universe - a kind of fictional regulatory body-that looks on and enables the reunion.

Extrapolated from Shakespeare's approving frame, the idea of renewable marriage plays with the presumed continuity of marriage, suggesting that marriage could be intermittent, or terminated and then resumed. ${ }^{65}$ It suggests a structure for the unfolding of relations between lovers over time, after growth and new appreciation of one for another. One might imagine variations: from the mistreated spouse who eventually forgives and returns, but only after remorse and recuperation by the abusive spouse, to the perhaps more fantastical permanent presumption in favor of a former spouse. Such a permanent presumption might confer privileges, such as ongoing access to a sexual relationship, even in the face of separation and reunion-that is, the former spouse might be an exception to new commitments of exclusivity or monogamy by the ex. ${ }^{66}$

A formal legal version of this is even more implausible, though not impossible. For instance, we might imagine a regime in which relations with a former spouse would not legally constitute adultery. ${ }^{67}$ The path of the older relationship worn into the new one would create a kind of sexual easement that persists despite new ownership.

This romantic elaboration of renewable marriage reads the play only through horizontal relations-that is, intimate, as opposed to parental,

65. Of course, at present, marriages can be terminated and then resumed, but this is done through divorce and remarriage, which follows the usual procedures for any new marriage, rather than invoking any special practice of renewing the first marriage. In principle, the closest legal analogue to renewable marriage might be the recent phenomenon that Jeannie Suk has termed "state-imposed de facto divorce," in which courts issue restraining orders in domestic violence situations, thereby prohibiting contact between the parties for a specified period ranging from two to eight years. See Jeannie Suk, At Home in the Law: How the Domestic Violence Revolution Is Transforming Privacy 40 n.55, 40-50 (2009). In practice, Suk does not think that reunion is likely if the parties actually separate for the designated period. See id. at 48 . Legal separation, which does not dissolve the marriage but determines certain legal rights between the parties, also might be understood as a form of renewable marriage. See, e.g., 27A C.J.S. Divorce $\S$ 349 (2010). And as a social matter, people do "renew their vows." Rachel Emma Silverman, "I Do, I Do, I Do, I Do" The Serial Vow Renewal, WALl ST. J., Aug. 28, 2003, at D1-D15. Where this is done to repair a rupture in the relationship, rather than to reaffirm a vibrant commitment, it might be understood as an emotional version of renewed marriage.

66. Think here of popular representations of a partner urging that a sexual dalliance doesn't "count" as infidelity because it involves an ex-lover, not a new lover. Of course, the betrayed lover generally does not see this purported exception the same way. See, e.g., Grace N' Glamour, Don at [sic] Justify Your Cheating, Sept. 14, 2009, http://www.gracenglamour.com/dont-justifyyour-cheating/. The emotional, rather than sexual, version of this access may be more accepted. That is, some kind of emotional closeness among former lovers-at least among great lovessometimes persists in one form or another even across subsequent serial monogamy; new lovers may be more inclined to feel they have to accept this kind of intimacy than physical intimacy.

67. Note that, though largely unenforced, nearly half the states still have adultery laws on the books. See Gabrielle Viator, Note, The Validity of Criminal Adultery Prohibitions After Lawrence v. Texas, 39 SufFolk U. L. REv. 837,837 (2006). 
relations. ${ }^{68}$ But The Winter's Tale does not focus merely, or even principally, on Hermione's relation to Leontes. ${ }^{69}$ Hermione gives us only one reason why she has returned to life: "to see the issue." her daughter Perdita has come back (bringing a spouse, who may be read as a kind of replacement son), and Perdita's return coincides with Hermione's. Perdita's reunion with Hermione is figured almost romantically. After her father notes that Perdita "stand[s] like stone with" her mother," in essence taking on her aspect, Perdita speaks to the statue: "Lady, / Dear queen, that ended when I but began, / Give me that hand of yours to kiss." ${ }^{72}$ Perdita's words literally describe the gap between them, in that mother and daughter just missed each other in time, with mother dying just after daughter was born. But her wording suggests romantic union: one person ends where the other begins. Perdita's final and only other line of the scene comes twenty lines before her mother's awakening. She sighs: "So long could I / Stand by, a looker-on."73

The play's emphasis on the vertical (parental) relation over the horizontal (intimate) relation may bring us to the more practical reason that spouses commonly reunite after breaks: to try again for the sake of the children. Even more, in contrast to the sexual easement I proposed above, the most common kind of easement a former spouse might have on the other takes the form of the dialogue, negotiation, and detailed knowledge of each other's lives necessary to coordinate their relationships with the children that came from their marriage. ${ }^{74}$ As noted elsewhere, family constructions in the contemporary United States look more transgressive when viewed through a child's eyes: the children of serial monogamists accumulate multiple parents, creating a kind of structural polyamory (or polyantipathy) from the child's perspective. ${ }^{75}$ Thus, the renewable marriage possibilities discussed here-while inviting us to reconsider our expectations about the conditions and terms of exiting

68. Cf. Frances E. Dolan, Dangerous Familiars 168 (1994) ("[Hermione] returns in order to forgive the father, not particularly for his role in the death of one child and the abandonment of another but for his jealous, tyrannical treatment of her.").

69. As Janet Adelman writes, in The Winter's Tale Shakespeare "opens up a space for the female narrative-specifically the mother-daughter narrative--his work has thus far suppressed." Janet Adelman, SufFocating Mothers 234 (1992).

70. SHAKESPEARE, supra note 60 at 160 (V.iii.121-28). Note the language of possession Hermione uses toward her daughter, with whom she so looks forward to conversing, evincing her focus on the future with her daughter. In her relation to Leontes, it is only his closing lines that emphasize plans for conversation between husband and wife.

71. Id. at 156 (V.iii.41).

72. Id. at 156 (V.iii.42-46).

73. Id. at 158 (V.iii.84-85).

74. We might think of this as a kind of unromantic antidote to Laura Kipnis's adultery imaginary, wherein Kipnis says we reinvent ourselves through the violations of normal life brought on by adultery: the children require a permanent presumption in favor of a former spouse, which is a constant recurrence of who we were in the past, within the marriage, in terms of shared obligations. See Laura Kipnis, Adultery, in INTimaCy 9, 40-43 (Lauren Berlant ed., 2000).

75. Emens, Monogamy's Law, supra note 3, at 298. 
marriage - may also be less radical than they at first appear.

\section{E. Solitary Marriage: Isolating and Self-Marriage}

Marriage is generally conceived of as a joining together. It thus seems contrary to, or at least apart from, solitude. But fictional and philosophical sources-low and high-invite us to consider solitude through marriage.

The poet Rilke, writing in an epistolary mode, urges a view of the good marriage as a path to solitude:

It is a question in marriage, to my feeling, not of creating a quick community of spirit by tearing down and destroying all boundaries, but rather a good marriage is that in which each appoints the other guardian of his solitude, and shows him this confidence, the greatest in his power to bestow. ${ }^{76}$

Rilke eschews the idea of a "togetherness" between people, viewing it as hindering "freedom and development." But, Rilke concludes,

[O]nce the realization is accepted that even between the closest human beings infinite distances continue to exist, a wonderful living side by side can grow up, if they succeed in loving the distance between them which makes it possible for each to see the other whole and against a wide sky! ? $^{78}$

Rilke's metaphor of the lovers always appearing to each other against a vast sky is not a form of structural countermarriage. He embraces our standard marital form -of two people facing each other and (presumably) only each other-but his rendition of marriage also imagines each spouse's role in the other's life not as co-entrant into a union but as a protector of the other's isolation: as the "guardian of his solitude."

The relation between marriage and solitude can take a bolder structural form: marriage to oneself. References to self-marriage appear occasionally in parodic criticism of same-sex marriage-as another place on the slippery slope that allegedly runs from same-sex marriage to polygamy. ${ }^{79}$ In popular fiction,

76. Rainer Maria Rilke, ON Love and Other Difficulties 28 (John J.L. Mood trans., 1975). Rousseau also depicts love as a place for the discovery of a vital solitude: "[D]uring those few years, loved by a gentle and indulgent woman ... [ $t$ ]he taste for solitude and contemplation grew up in my heart along with the expansive and tender feelings which are best able to nourish it." Jean-Jacques Rousseau, Reveries of a Solitary Walker 154 (Peter France trans., 1979) (1782).

77. RıLKE, supra note 76, at 28 (emphasis omitted).

78. Id. (emphasis in original).

79. For instance, one comment to the news on New Hampshire's lifting of the ban on samesex marriage wrote:

Marriage is now meaningless in the Granite State. It's only a matter of time before other special interest groups argue for their "rights," and the precedent set here will allow them to get their way. Want to marry two women? Sure. Ten men. Okay! Want to marry yourself? Why not, can't discriminate.

Tom Fahey, Same-Sex Marriage Becomes Law in NH, UnionLeader.com, June 3, 2009, http://www.unionleader.com/article.aspx?headline=Samesex $\% 2 \mathrm{Bmarriage} \% 2 \mathrm{Bbecomes} \% 2 \mathrm{Blaw}$ 
the idea of marrying oneself is elaborated slightly more seriously in an episode of the HBO series Sex and the City. ${ }^{80}$ There, the lead character, Carrie, decides to announce to a friend that she is marrying herself and registering for a particular pair of shoes. Carrie's intention is to make her friend realize how much Carrie has spent on the friend's life events, from wedding presents to baby showers. The friend had insulted Carrie for spending too much on a pair of Manolo Blahnik shoes that went missing at the friend's baby shower, where guests were required to remove their shoes for the health of their toddler. On learning the shoes were gone, and after some prompting, the friend had offered to pay for the missing shoes. But when she heard they cost nearly $\$ 500$, she reneged, intimating that her own grown-up married life with children leaves no room for trivial expenditures such as high-end shoes. Carrie fumes as she adds up how much she has spent on her friend's life choices-for her engagement and wedding and babies-expenditures that may never come back to Carrie. So she decides to leave a voicemail for her friend, announcing her marriage to herself and her registry at one place: the shoe store Manolo Blahnik. The friend finally seems to understand Carrie's point of view and buys the shoes for her, sending a note saying she hopes that "you and you will be very happy."

The episode's flirtation with self-marriage has a serious side: the wealth transfer from single people to married people that custom often dictates. That wealth transfer has legal and institutional dimensions, in terms of the state and workplace benefits that marriage provides to (at least some forms of) married couples. ${ }^{81}$ Social status also accompanies marriage, as is often noted in contemporary marriage debates; for many it signifies, among other things, entry into stable adult life. ${ }^{82}$ In this light, that someone might want to marry herself sounds like less of a joke, if still fanciful.

\%2Bin\%2BNH\&articleId=ac4816el-7ac9-4694-b89c-b6174c8b6a87 (quoting Alex, Nashua).

80. Sex and the City: A Woman's Right to Shoes (HBO August 17, 2003).

81. For instance, in the United States, male-female married couples within certain income ranges receive a federal tax benefit if their income disparity is great enough, but not if their incomes are similar. See, e.g., Shari Motro, A New "I Do": Towards a Marriage-Neutral Income Tax, 91 IowA L. REv. 1509 (2006), available at http://papers.ssm.com/sol3/papers.cfm? abstract_id=894104; Alternatives to Marriage Project, Legal and Financial Issues, http://www.unmarried.org/legal-financial.html (last visited Jan. 2, 2011). Workplaces provide various kinds of family benefits, the costs of which may be bome at least in part by single (or childless) colleagues. See, e.g., Mary Anne Case, How High the Apple Pie?, 76 CHI.-Kent L. REV. 1753 (2001).

82. See, e.g., Robin Marantz Henig, What Is It About 20-Somethings?, N.Y. TimEs MAG., Aug. 18, 2010, at MM28, http://www.nytimes.com/2010/08/22/magazine/22Adulthood-t.html. Moreover, some people might relish the potential for marriage to narrow one's social world - to take one "off the market," as it were. 


\section{F. Exculpatory Marriage: The Ultimate Benefit}

Before I discuss Never Let Me Go ${ }^{83}$ a warning to the reader: this Section gives away the twist of this wonderful novel, and can be skipped without ruining your reading of the rest of the Essay.

In Never Let Me Go, Kazuo Ishiguro, the author of The Remains of the Day, ${ }^{84}$ applies his subtle appreciation of human relations to a subject more typical of science fiction. Ishiguro portrays a dystopic society where the powers that be have created a race of clones. These clones are kept in institutions so that eventually their organs may be harvested for the benefit of the regular citizens. Society exploits some of the clones not only for their bodies but for their labor: these latter clones act as caregivers for others who, as a result of the organ harvesting process, are growing gradually weaker on their road to an early death (or "completion," as the novel puts it).

The novel's poignancy turns on two of its features. One is the gradual unfolding for the narrator, Kathy, of the truth of her own identity as a clone and of this grotesque societal arrangement; she in turn reveals the rules of her world to the reader bit by bit. The other is the love between two of the clones-Kathy and Tommy, a boy with whom she went to "school" before either knew they were clones-and the rumor that emerges about love as a way out of the early death to which clones are consigned. As Kathy cares for a childhood friend before the latter's completion, the friend reveals the underhanded way in which she had long ago come between Kathy and Tommy, who had always loved each other. She urges Kathy to reconnect with Tommy, to pursue their love, and to seek from the authorities a special dispensation rumored among the clones.

The rumor is that clones can have their organ donations, and thus their premature death, "deferred"- "if they're really in love." 85 Tommy and Kathy journey to the authorities who had run their school so many years ago. The lovers plead their case, only to learn that the rumor is false. There is no way to defer their donations; their love cannot save them. The novel thus beautifully renders, and then shatters, a classic and deeply human fantasy: that love can save us from our own mortality.

In so doing, the novel also portrays a fantastical vision of the benefits the state could bestow on deserving lovers. State-recognized relationships-that is, what we currently tend to call marriage-can involve any number of statesponsored benefits (and burdens). ${ }^{86}$ In Ishiguro's rendering, the state is rumored to have a regulatory regime that bestows the ultimate benefit on deserving

83. Kazuo Ishiguro, Never Let Me Go (2005).

84. Kazuo Ishiguro, The Remains of the Day (1989).

85. IsHIGURO, supra note 83, at 174.

86. See infra text accompanying note 103 . 
couples: life. Those scheduled for execution, for an untimely death by order of the state, could be pardoned, spared-if their love takes the right form. We might call this exculpatory marriage. The novel rejects this rumor, but nonetheless leaves us with a striking vision of a state that could select and recognize only a chosen few for a kind of marriage whose benefit is the right to live.

The possibility of exculpatory marriage drawn from Ishiguro's world, though extreme, looks less absurd if we recognize the ways that our current legal system allows people effectively to "contract around" the criminal law. For instance, in some states, the (in some ways contractual) relationship of marriage is a defense to statutory rape. ${ }^{87}$ (And of course marriage is a defense to fornication, ex ante if not ex post.) Consent to sex might similarly be understood, though it sounds crass to many ears, as a form of contract that converts rape into legal sex. ${ }^{88}$ Contracting to make pornographic films can allow one to pay others to have sex without running afoul of prostitution laws. ${ }^{89}$ The Ishiguro example draws our attention to this feature of existing law and urges us to imagine the broadest possible range of benefits that marriage law could confer.

\section{G. The End of Marriage}

Following this brief tour of fictional rewritings of our marriage regime, let us return to Shakespeare for the ultimate countermarriage proposal-Hamlet's call for the end of marriage:

Ham. I have heard of your paintings well enough. God hath given you one face, and you make yourselves another. You jig and amble, and you [lisp,] you nick-name God's creatures and make your wantonness [your] ignorance. Go to, I'll no more on't, it hath made me mad. I say we will have no mo[r]e marriage. Those that are married already (all but one) shall live, the rest shall keep as they are. To a nunn'ry, go. ${ }^{90}$

It is hard to read Hamlet's imagined world without marriage as anything positive, given its inclusion in his rant against Ophelia. Hamlet's spiteful railing against the institution may remind us of Goethe's Count, whose own

87. See, e.g., Ariz. Rev. STAt. ANN. § 13-1407 (2010) ("It is a defense to a prosecution pursuant to $\S 13-1404$ [nonconsensual sexual conduct] or 13-1405 [sexual conduct with minor] that the person was the spouse of the other person at the time of commission of the act.").

88. And of course, to other ears, sex always bears an important relation to rape. See, e.g., Catharine A. Mackinnon, Toward A Feminist Theory of the State 128 (1989).

89. See People v. Freeman, 758 P.2d 1128 (Cal. 1988). Freeman doesn't focus on the contractual point, but the structure of the arrangement seems to be one in which the parties have contracted out by agreeing to this third purpose-beyond the purpose of sexual gratification, which the court focuses on as the thrust of the prostitution statute at issue-of making films. Note that, beyond sex and marriage contexts, other examples of contracting around the criminal law include the practice of plea bargaining and laws exempting sports activities from assault laws. See, e.g., IOWA CODE $\S 708.1$ (2010).

90. William Shakespeare, The Tragedy of Hamlet, Prince of Denmark act 3, sc. 1 (alterations in original but for "mo[r]e"). 
embitterment may be seen to fuel his personal interest in alternatives to marriage. ${ }^{91}$ Remember, however, that one of the Count's variations on marriage-exploding marriage - might be read as more romantic than cynical, leaving us with two different versions of what may inspire a turn to marriage alternatives. $^{92}$

We need not linger over the basic idea of ending marriage, as it has been addressed at length in the same-sex marriage debates. Due attention has been paid to the question whether we should get the state out of marriage altogether and just permit adults to organize their intimate affairs through private contract law. Scholars have proposed various rationales for this contractual regime, including refocusing the state's attention and resources on relations of dependency $;^{93}$ getting the state out of an institution with historical associations with coverture and other legal impairments for women; ${ }^{94}$ paving the way for religions to define marriage more purely according to their faith, rather than having to accept a compromised version through the state; ${ }^{95}$ and prompting partners to make more active choices about the kinds of relationship they want to have under law as well as the role they want law to play in their relationship. ${ }^{96}$ Since this Essay aims to unearth regulatory possibilities that have not been examined in these debates, I now turn to a source that manages to push the concept of ending marriage yet another step further: to a world not only without marriage, as Hamlet envisioned, but also without any contracts between intimate partners.

91. See supra note 36 and accompanying text.

92. Id. Two rather different readings of Hamlet's world without marriage are also available from his words: a libertine and a celibate one. "Nunnery" had the contemporary sense of "brothel" as well as "convent." See Oxford English Dictionary (draft revision Sept. 2010) (defining "nunnery" as such and offering the following first example: "1593 Christs Teares 79 b, [To] some one Gentleman generally acquainted, they giue..free priuiledge thenceforward in theyr Nunnery, to procure them frequentance.").

93. This position is most notably associated with Martha Fineman. See MARTHA Albertson Fineman, The Autonomy Myth: A Theory of Dependency (2004); Fineman, supra note 2; see also Nancy D. Polikoff, Ending Marriage As We Know It, 32 Hofstra L. Rev. 201, 204-05 (2004) (criticizing the U.S. focus on narrowly reforming marriage and holding up as a model alternative the 2001 Law Commission of Canada's Report: Beyond Conjugality: Recognizing and Supporting Close Personal Adult Relationships, Dec. 21, 2001, available at http://www.samesexmarriage.ca/docs/beyond_conjugality.pdf); Nancy D. Polikoff, Why Lesbians and Gay Men Should Read Martha Fineman, 8 AM. U. J. Gender SoC. PoL'y \& L. 167 (1999).

94. See, e.g., Cain, supra note 4 (discussing these and other arguments); Cass R. Sunstein, The Right to Marry, 26 CARDozo L. REv. 2081 (2005) (same).

95. Cf. Kmiec Proposes End of Legally Recognized Marriage, Catholic News AGEnCY, May 28, 2009, http://www.catholicnewsagency.com $/$ news/kmiec_proposes_end_of_legally_ recognized_marriage/; Douglas W. Kmiec \& Shelley Ross Saxer, Equality in Substance and in Name, S.F. Chron., Mar. 2, 2009; $c f$. also Martha C. Nussbaum, From Disgust to Humanity: Sexual Orientation \& Constitutional Law 163 (2010) (noting, without elaborating, her support for this approach).

96. See, e.g., JuSt MARRIAGE, supra note 2 (various essays); David L. Chambers, For the Best of Friends and for Lovers of All Sorts, 76 NoTRE DAME L. REv. 1347 (2001). 
II.

\section{LAW AS SCIENCE FICTION}

The countermarriage possibilities imagined through fiction took us far from our current marriage regime in a variety of ways, inventing alternatives to contemporary practice. Yet, these possibilities all remained forms of marriage. They largely maintained familiar structures such as consent, duration, and commitment, while countering our usual expectations of how those features might work. Even Hamlet's imagining of the end of marriage was defined entirely by the familiar form of marriage $;^{97}$ Hamlet merely posited the absence of such a thing.

This Section explores a regulatory universe even further afield from current marriage law. ${ }^{98}$ The inspiration for this brave new world is, perhaps ironically, legal rules generated in the name of preserving marriage against the threat of same-sex relationships: the so-called mini-DOMAs. The miniDOMAs are the Defense of Marriage Act statutes and amendments passed by many states in recent years to preserve traditional, different-sex marriage against the perceived threat of same-sex relationships. ${ }^{99}$ These laws do not merely declare the absence of marriage for same-sex couples. In their most extreme form, these laws threaten to ignore certain types of contracts between same-sex partners. Extrapolating from such laws, we can envision a dramatic alternative to our marriage regime: a world not only without marriage, but without any private contracts between intimate partners.

To imagine the possibilities generated by these laws, I use a particularly sweeping example of a mini-DOMA-a Virginia statute passed in 2004. This statute is one of many intriguing mini-DOMAs, including others passed in the state of Virginia. ${ }^{100}$ But this 2004 Virginia statute is of particular interest

97. Of course, marriage in Hamlet's time is not an entirely familiar form, in light of the dramatic changes in marriage over time. See, e.g., NancY CotT, Public Vows (2000); Case, Marriage Licenses, supra note 16.

98. Anti-gay law also offers material that could be mined for marriage variations more akin to those discussed in Part I. For instance, we could draw out a category akin to those above by looking to cases that find that same-sex relations do not count as adultery. See, e.g., In re Blanchflower, 834 A.2d 1010, 1011 (N.H. 2003) (holding that sex between two women did not constitute adultery under New Hampshire's fault divorce statute, based on the dictionary definition of "sexual intercourse"). We might (inelegantly) call this asymmetrical gender exclusivity. A social version of this structure is suggested by the web site http://www.pornfidelity.com/, in which a married couple has claimed a niche in the porn industry by inviting others into bed with them, invoking slogans like "The couple that plays together, stays together," and yet engaging in sex outside their marriage only with other women. For legal variations on the exploding marriage theme, see supra note 29.

99. See Andrew Koppelman, The Difference the Mini-DOMAs Make, 38 LoY. U. CHI. L.J. 265 (2007) (explaining the term and the status of these acts, inter alia). Mini-DOMA is the term coined to describe a state-level version of the federal Defense of Marriage Act (DOMA), passed in 1996.

100. Virginia first passed a mini-DOMA statute focusing on same-sex marital relationships:

A marriage between persons of the same sex is prohibited. Any marriage entered into 
because it explicitly targets "partnership contracts." Setting aside the law's discriminatory aspect, I focus instead on what it might mean to treat a law like this as the starting point for an alternative regulatory regime for everyone. In so doing, I also show how law opens up imaginative possibilities through what I call "law as science fiction."

Here is the language of the 2004 statute banning, inter alia, same-sex "partnership contracts":

Civil unions between persons of same sex. A civil union, partnership contract or other arrangement between persons of the same sex purporting to bestow the privileges or obligations of marriage is prohibited. Any such civil union, partnership contract or other arrangement entered into by persons of the same sex in another state or jurisdiction shall be void in all respects in Virginia and any contractual rights created thereby shall be void and unenforceable. ${ }^{102}$

The statute is puzzling to say the least. First, what does it cover? What is included in these words: "partnership contract or other arrangement . . . purporting to bestow the privileges or obligations of marriage"? Indeed, the language is so broad that one might ask: What is not included? The scope of the statute is interesting in its own right, so I will pause over it here.

\section{A. The Scope of the Statute}

The "privileges or obligations of marriage" are vast. They include benefits and burdens directly bestowed by the state and those granted by third parties, as well as those that partners bestow on one another exclusively or principally. Though state laws vary, state and federal laws affecting marriage broadly include tax benefits and burdens for spouses; immigration benefits; evidentiary privileges; inheritance benefits and obligations; surrogate decision-making responsibilities; parenting presumptions; special forms of property ownership; various veterans' benefits; statutory privileges (such as caretaking leave time under the Family Medical Leave Act); and a legal mechanism and default rules

by persons of the same sex in another state or jurisdiction shall be void in all respects in Virginia and any contractual rights created by such marriage shall be void and unenforceable.

VA. CODE ANN. $\$ 20-45.2$ (2004). Only a few years later, Virginia passed an expansively worded constitutional amendment:

[O]nly a union between one man and one woman may be a marriage valid in or recognized by this Commonwealth and its political subdivisions.

This Commonwealth and its political subdivisions shall not create or recognize a legal status for relationships of unmarried individuals that intends to approximate the design, qualities, significance, or effects of marriage. Nor shall this Commonwealth or its political subdivisions create or recognize another union, partnership, or other legal status to which is assigned the rights, benefits, obligations, qualities, or effects of marriage.

VA. CoNST. art. I, $\S 15-A(2006)$. My focus in this Essay is a third law passed between the time of the statute and of the amendment.

101. See supra notes 12-13 and accompanying text (discussing this term).

102. VA. Code ANN. $\$ 20-45.3$. 
for divorce, inter alia. ${ }^{103}$ Beyond these features created by government, marriage entails a wide range of privately bestowed benefits and burdens, such as hospital visitation rights; employment-related health benefits; shared club membership privileges; presumptively shared names (benefit or burden, depending on your view); and often public ceremonies (and the costs, gifts, and status those entail), to name a few. Marriage also comprises various privileges and obligations that spouses grant each other. These typically include presumptive or explicit sexual exclusivity; first or high priority for time, attention, and caretaking in the event of illness; presumptive personal loyalty; completely or partially shared resources; holiday gifts; shared living space; and kin work. ${ }^{104}$ The sheer volume of these marital "privileges or obligations" makes the scope of the Virginia statute a puzzle.

Who does the Virginia statute prohibit from making what arrangements under what circumstances? One could speculate endlessly about what the statute might cover. The statute surely does more than prohibit recognition of out-of-state same-sex marriages, since Virginia already had a statute specifically targeting these. ${ }^{105}$ Beyond that, the statute's meaning is far from clear. ${ }^{106}$ Here are a few possible readings. As I will discuss, the statute invites us to think beyond the end of marriage and imagine countermarriage regimes for all relationships.

103. See, e.g., Goodridge v. Dep't of Pub. Health, 798 N.E.2d 941, 955-56 (Mass. 2003); Anita Bernstein, For and Against Marriage: A Revision, 102 MiCH. L. REV. 129 (2003); David L. Chambers, What If? The Legal Consequences of Marriage and the Legal Needs of Lesbian and Gay Male Couples, 95 Mich. L. REv. 447 (1996); Cass R. Sunstein, The Right To Marry, 26 Cardozo L. Rev. 2081 (2005).

104. Most of these are neither necessary nor unique to marriage, but most are arguably typical. For more on kin work, see Micaela di Leonardo, The Female World of Cards and Holidays: Women, Families and the Work of Kinship, 12:3 SIGNS 440, 442 (1987) (coining the term "kin work," which refers to "the conception, maintenance, and ritual celebration of crosshousehold kin ties..." ).

105. See supra note 100 .

106. Virginia courts have offered some limited interpretation of the statute thus far. In Stroud v. Stroud, 641 S.E.2d 142 (Va. Ct. App. 2007), a court of appeals held that the two Virginia statutes cited above bore no relevance to its decision to terminate an ex-wife's alimony upon her cohabitation with another woman. Pursuant to a divorce property settlement agreement, the wife's alimony would be terminated upon "the remarriage of Wife and/or her cohabitation with any person to whom she is not related by blood or marriage in a situation analogous to marriage for a period of thirty (30) or more continuous days." Id. at 145 (emphasis in original). In addition, the Attorney General issued an opinion letter when Virginia was considering its miniDOMA constitutional amendment in 2006, quoted supra note 100 , offering a narrow interpretation of existing law along with the pending amendment. The Attomey General essentially read these laws not to interfere with basic contractual and other rights that were not unique to marriage-in other words, he read these mini-DOMAs narrowly to apply only to rights unique to marriage. Opinion Letter from Attomey General Robert F. McDonnell to the Honorable Stephen D. Newman et al., No. 06-003, 2006 WL 4286442 (2006). As the court pointed out in Stroud, opinion letters by the Attorney General are not binding on the courts. 641 S.E.2d at 151 . 
1) State-created civil unions only. The statute might be read to refer only to official civil unions formed in other states. At first glance, this reading looks promising. For instance, the title of the statute- "Civil unions between persons of same sex"-supports this interpretation by mentioning only civil unions. And while we can assume that the words "partnership contract or other arrangement" following "civil union" were significant to the legislature-since it rejected the governor's proposal to remove those words ${ }^{107}$ - the purpose of those words could merely be to make sure the statute covers any civil-uniontype status that another state might create, whatever the name.

But there are features of the statute that cut against this reading. For instance, there is a superfluity problem if the statute refers only to other states' statuses, since the second sentence of the statute expressly concerns unions from other jurisdictions. Moreover, both the version of the statute first introduced in the House and the amended version the House initially passed contained only language about unions and contracts created in other jurisdictions. ${ }^{108}$ Late in the amending process, the Senate Committee for Courts of Justice incorporated the first sentence of the final statute. ${ }^{109}$ In light of the

107. HB 751 Governor's Recommendation, Virginia Bill Tracking - 2004 Session, http://leg1.state.va.us/cgi-bin/legp504.exe?041+amd+HB751AG.

108. The main sponsor of the bill, Representative Marshall, initially put forward two versions of the bill: H.B. 750 (which Marshall proposed alone and which contained an additional line declaring a state of emergency), and H.B. 751 (which lacked the state of emergency language and which several other representatives joined). See H.B. 750, 2004 H. Dels., 2004 Sess. (Va. 2004), http://leg1.state.va.us/cgi-bin/legp504.exe?041+sum+HB750 (legislative summary for H.B. 750); H.B. 751, 2004 H. Dels., 2004 Sess. (Va. 2004), http://leg1.state.va.us/cgibin/legp504.exe?041+sum+HB751 (legislative summary for H.B. 751) [hereinafter H.B. 751 Summary]. H.B. 751 eventually underwent revisions and became the final statute. H.B. 751 Summary. The language of H.B. 751, as originally proposed, was as follows:

The General Assembly hereby concludes that the Commonwealth of Virginia is under no constitutional or legal obligation to recognize a marriage, civil union, partnership contract or other arrangement purporting to bestow any of the privileges or obligations of marriage under the laws of another state or territory of the United States unless such marriage conforms to the laws of this Commonwealth.

H.B. 751, 2004 H. Dels., 2004 Sess. (Va. 2004), http://leg1.state.va.us/cgi-bin/ legp504.exe?041+ful+HB751 [hereinafter H.B. 751 Proposed]. The additional line in Marshall's alternative and ill-fated version read: "That an emergency exists and this act is in force from its passage." H.B. 750, 2004 H. Dels., 2004 Sess. (Va. 2004), http://leg1.state.va.us/cgi-bin/ legp504.exe?041+ful+HB750. The version that the House passed, amended by the House Committee for Courts of Justice on Feb. 6, 2004, reads:

The General Assembly declares as its existing public policy that the Commonwealth of Virginia does not recognize a marriage, civil union, partnership contract, or other arrangement purporting to bestow the privileges or obligations of marriage under the laws of another state or territory of the United States unless such marriage conforms to the provisions of Chapter 2 of Title 20 ( $\$ \S 20-13$ et seq.).

H.B. 751, 2004 H. Dels., 2004 Sess. (Va. 2004), http://leg1.state.va.us/cgi-bin/ legp504.exe?041+ful+HB751H1. Finally, on March 8, 2004, the Senate Committee for Courts of Justice proposed the amended version of the statute that incorporated the language that was finally enacted. H.B. 751, 2004 H. Dels., 2004 Sess. (Va. 2004), http://legl.state.va.us/cgi-bin/ legp504.exe?041+ful+HB751S1.

109. H.B. 751, 2004 H. Dels., 2004 Sess. (Va. 2004), http://legl.state.va.us/cgi-bin/ legp504.exe?041+ful+HB751 ("Whereas, persons who wish to dispose of their property or assign 
statutory superfluity point, and the timing of the introduction of that first sentence, the statute seems to target something broader than merely out-of-state civil unions.

2) All of marriage. Perhaps the statute narrowly covers only those agreements that include all of the rights and obligations of marriage that private contract can confer, that is, those agreements that attempt to replicate marriage as closely as possibly through private contract. This reading would seem consistent with the idea of trying to prevent harm to the institution of marriage by preventing attempts to copy it. It also has the advantage that a court could probably determine from the four corners of an agreement whether the statute covered it. The difficulty with this reading, however, is the statute's reference to the "privileges or obligations" of marriage, rather than the privileges and obligations. Because an exact copy of marriage would include both privileges and obligations, rather than one or the other, this reading strains against the statutory language.

3) Platonic relationships. The statute might, in principle, disregard romantic involvement. On its face the statute says nothing about homosexuality or romantic relationships. Could the statute apply to a partnership agreement between two male doctors that creates a joint medical practice and conveys the practice to the survivor if one of the partners dies? This borders on the absurd. The legislative history ${ }^{10}$ makes plain that the statute's concern is homosexuality. Presumably, only a judge wishing to gain popular support for striking the statute down would read the statute this way (though, interestingly, it might also help the statute escape Romer-type problems). ${ }^{111}$

4) Speaking "marriage." Perhaps the word "marriage" matters. Maybe a court could sort those arrangements that purport to bestow the relevant privileges or obligations from those that don't by looking to whether the word "marriage" appears in the agreement. This might seem unduly formalistic, but, like the "all of marriage" reading above, it would simplify coverage determinations. Of course this would also probably mean a great deal of overbreadth (since "marriage" has meanings beyond romantic marriage ${ }^{112}$ ) and

the power of attorney to another person in case they are sick or disabled are legally authorized to do so at present without regard to any legal impediment or qualification regarding their sexual orientation.").

This aspect of the process helps to make sense of the fact that the only document in the legislative history - a proposers' preamble (an otherwise unheard-of type of legislative document in Virginia, according to librarians at University of Virginia, the VA State Law Library, and the Virginia Assembly, as reported to Beth Williams, librarian at Columbia Law School)-speaks only of the civil unions of other states and even asserts that same-sex couples can obtain enforcement of private agreements just like anyone else.

110. See sources cited supra note 108.

111. Romer v. Evans, 517 U.S. 620 (1996); see infra note 116.

112. For example, what if our platonic male doctor friends discussed above used the word "marriage" in their contract to convey the closeness of their business relationship (perhaps one of them was an avid reader of the OED)? Presumably, under this reading the statute would reach 
underbreadth (since the M-word might not be used in romantic situations for any number of reasons). ${ }^{113}$

5) Contextualized overlap with marriage. That we can speak of overbreadth and underbreadth suggests we have some idea of the core of the statute. The context-the relationship of the parties, most importantly, and probably their intent in entering the agreement-would seem to matter. The public nature of their relationship and any associated ceremony might be sufficient (but not necessary) to bring any contracts they formed within the statute's scope. And so, in addition to applying to civil unions from other jurisdictions, the statute would apply to any arrangement between romantically involved same-sex partners that concerned most or many of the key privileges or obligations of marriage. And more broadly, the statute might well mean nonenforcement of any individual agreement between same-sex partners that overlaps with a specific privilege or obligation of marriage. ${ }^{114}$ This might also reach any third-party agreement that benefitted them, such as a healthinsurance policy covering same-sex partners. ${ }^{115}$

6) Any agreement between same-sex intimate partners. Which of the above interpretations a judge would choose could plausibly depend on whether the judge wanted to uphold or strike down the statute, or, otherwise, how the judge sought to resolve the dispute at hand. ${ }^{116}$ But in light of the previous

them.

113. For instance, the statute wouldn't affect two women in a long-term sexual partnership who make an agreement tracking marriage law as closely as possible-in order to try to get around the fact that marriage itself is unavailable to them-if they chose not to use the M-word, for instance, because of simple omission, an attempt to evade the statute, or a wish not to be associated with the institution of marriage for feminist or other reasons). Cf. Paula Ettelbrick, Since When Is Marriage a Path to Liberation?, Out/Look Nat'l Lesbian \& Gay Q., Fall 1989, at 14.

114. Related to this, a court that thinks the aim of the statute is to get at bundlings of privileges and obligations might still think that any agreement covering just one such privilege or obligation could be an effort to end-run the statute by building up such a bundling gradually.

115. This is even setting aside the question whether "prohibited" might mean something more than legal but not enforceable-for instance, criminal. $C f$. Martha A. Field, Surrogate Motherhood: The Legal and HUMAN Issues (1990) (arguing for a treatment of surrogacy contracts as legal but unenforceable). Note, though, that the second sentence of the statute refers to other jurisdictions' contracts being "void" whereas the language in the first sentence is "prohibited," suggesting that "prohibited" in the first sentence was chosen carefully and has some meaning distinct from "void." The language of prohibited rather than void might seem to imply the criminalization of such contracts - much like for prostitution or conspiracy agreements (or in some places, surrogacy agreements). But without any express mention of the criminal law and any penalties, this seems a stretch.

116. Plausible grounds for striking down the statute would include equal protection via Romer v. Evans, 517 U.S. 620 (1996). The broader the scope of the statute, the harder it becomes to say that the statute's sole purpose is to protect the traditional meaning of marriage rather than to single out lesbians and gays for special legal burdens (to the extent that that distinction holds at all). The statute is presumably prospective, not retrospective, but if it were read as the latter, it would presumably violate the Contracts clause. Cf. Douglas W. Kmiec \& John O. McGinnis, The Contract Clause: A Return to the Original Understanding, 14 HASTINGS Const. L.Q. 525 (1987); see also supra note 106 (discussing limited interpretation of the statute thus far). 
interpretation offered, anyone in a same-sex romantic relationship could understandably be concerned that in the context of his relationship, any contract with his partner might not hold up in court. ${ }^{117}$

This final possibility brings us to a very different kind of inquiry.

\section{B. Freedom for All: Applying a Broad Reading Broadly}

One thing (and perhaps only one thing) is clear from the Virginia statute: it covers only persons of the same sex. A man and a woman together doing any of the things potentially proscribed by the statute fall outside its purview. But what if that weren't so? What if the statute applied to everyone?

A generalized version of the statute invites us to imagine a starkly different legal regime. ${ }^{118}$ It suggests the possibility of a world in which any contract (whether a partnership contract or otherwise) between intimate partners (whether same-sex or opposite-sex) is void and unenforceable.

Taking the Virginia statute's first sentence as our focus, we can imagine a generalized version:

A civil union, contract, or other arrangement purporting to bestow the privileges or obligations of marriage is prohibited.

The world of the revised statute could take either of two forms. In one version, all other laws would stay as they are, so marriage would remain in place, and the only difference from our current world would be that no romantically involved couples, either straight or gay, could create enforceable contracts that overlap with marriage's privileges or obligations. Such a regime might comport with the state's interest in promoting traditional marriage and in preventing alternative arrangements from "weakening the institution of marriage which is foundational to this country's history and tradition." "119 But the second version of this alternative legal regime is more interesting.

Under the second imagined regime, there would not only be no marriage, there would be no enforceable contracts between intimate partners. I am not advocating such a world, nor am I predicting it as in any way a plausible eventuality. ${ }^{120}$ In this imagined world, though, people in romantic relationships

117. Of course, contracts-express or implied-that trade in sex are generally not enforceable. But even Hewitt, which feared that enforcing a cohabitant agreement would diminish the institution of marriage, recognized that "cohabitation by the parties may not prevent them from forming valid contracts about independent matters, for which . . . sexual matters do not form any part of the consideration." Hewitt v. Hewitt, 394 N.E.2d 1204, 1208 (Ill. 1979). What I am discussing here, by contrast, are contracts that do not have sex as any part of the considerationsuch as contracts concerning a business partnership - but that, hypothetically, might nonetheless be invalidated simply because the parties are sexually involved.

118. Such a version would also narrow the range of possible constitutional objections to the statute. Cf. supra note 116.

119. H.B. 751 Proposed, supra note 108.

120. Thus, I do not attempt to define the precise contours of such regime, such as how the state would define and prove romantic relationships for these purposes, or how legal relations to children would be determined. Note, though, that this hypothetical regime has historical 
would not be able to marry or to form any legally enforceable agreements with each other.

Although this might seem absurd, it is possible to generate reasons for refusing to enforce contracts between romantic partners, regardless of how unlikely such a refusal is. First, the state might be concerned about bounded rationality among contracting partners. ${ }^{121}$ That is, a state might plausibly think that romantic partners are peculiarly bad at making sensible contracting decisions. Such partners may be overly optimistic about the future, as people on the verge of marriage tend to be. As Pollock and Maitland famously said, "[o]f all people in the world lovers are the least likely to distinguish precisely between the present and the future tenses."122 They therefore may create contracts that do not properly assess risks and eventualities. Optimism and cloudy thinking may override the cautionary function of legal formalities. ${ }^{123}$

An inability to make rational, independent decisions underpins some standard reasons that we decline to enforce otherwise valid contracts. Think here of duress, undue influence, or even incapacity. We might think of lovers as like those whose will is overborne, or like drunk people or children, in their relations with each other.

Second, the state might be unwilling to hold lovers to their contractual obligations because of paternalistic concerns. As with infancy or mental incapacity, we may worry that inequality in the relationship will produce terms more favorable to one party in a way that is substantively unfair. ${ }^{124}$ We thus free our most vulnerable citizens from obligations they may unwittingly incur. Of course, to stretch this concern about vulnerability into a refusal to enforce any such contracts seems excessive. But the aim here is to entertain unusual possibilities, not to devise an ideal regime.

Third, if the parties aren't making rational decisions, then their agreements may be less likely to have the features that lead us, under a welfare

analogues, for instance, in the situation of mixed-race couples in states with antimiscegenation laws before Loving v. Virginia, 388 U.S. 1 (1967), and Marvin v. Marvin, 557 P.2d 106 (Cal. 1976). On Marvin, see infra note 137.

121. Brian H. Bix, Choice of Law and Marriage: A Proposal, 36 FAM. L.Q. 255, 270 (2002) (defining bounded rationality as "people's natural inability to calculate rationally or effectively about certain matters" and observing that "[t]here is some argument that the problem of bounded rationality might be particularly important for parties' bargaining about marriage"); Melvin Aron Eisenberg, The Limits of Cognition and the Limits of Contract, 47 STAN. L. REV. $211,254-58$ (1995) (arguing, on the basis of bounded rationality concerns, that courts should evaluate prenuptial agreements for "whether, in light of all relevant factors, the parties were likely to have had a mature understanding that the agreement would apply even in the kind of marriage scenario that actually occurred").

122. 2 Sir Frederick Pollock \& Frederic William Maitland, The History of ENGlish LaW Before the Time of Edward I 368-69 (photo. reprint 1968) (2d ed. 1898).

123. Cf. Lon L. Fuller, Consideration and Form, 41 Colum. L. Rev. 799 (1941).

124. These were of course among the reasons adduced for not enforcing prenuptial agreements, in addition to the problem that they contemplated the end of marriage. See, e.g., Simeone v. Simeone, 581 A.2d 162 (Pa. 1990). 
rationale, to enforce contracts. ${ }^{125}$ That is, the parties, by not pursuing their individual self-interest, may not achieve a surplus; the contract they create may not be Pareto optimal. ${ }^{126}$ Classic contracting parties are those who stand "at arm's length." Where the parties' judgment is boundedly rational to the extent of lovers', then their contracts may simply be less likely to be welfarepromoting. If so, why would the state waste resources enforcing such agreements? ${ }^{127}$

Related to this welfare rationale for non-enforcement is a separate concern: enhanced enforcement costs. The state might prefer not to enforce contracts between lovers in order to avoid the costs to the state of such enforcement. ${ }^{128}$ Contracts formed between lovers could disproportionately result in litigation costs. Picture two sets of contracting parties: $A B$ and $C D$. Each set creates a business partnership. The only difference between them is that $\mathrm{A}$ and $\mathrm{B}$ are romantically involved while $\mathrm{C}$ and $\mathrm{D}$ are not. Which venture seems more likely to fail? The state might plausibly predict $A B$. In addition, a state might well predict that even if both $A B$ and $C D$ fail, then $A B$ is more likely to end up in litigation. To paraphrase Bob Ellickson, the conflicts that end up in court, and thus in casebooks, disproportionately involve "sociopaths and love triangles." 29 For any number of paternalistic or cost-based reasons, then, a state might prefer not to enforce contracts between lovers.

This alternative world seems obviously implausible, or even impossible. A world where lovers can neither marry nor contract sounds ludicrous-the mad musings of a legal scholar gone awry. But this scheme is not too far removed from the world contemplated for same-sex couples in Virginia. The state of Virginia thus imaginatively forces us all into this alternative legal world - the world of no marriage and no contracts.

125. For a thumbnail sketch of a welfare rationale for contract enforcement, see Louis Kaplow \& Steven Shavell, Fairness Versus Welfare, 114 HARv. L. REV, 961, 1102 (2001) ("From the perspective of welfare economics, the purpose of contracts is to promote the well-being of the contracting parties ....").

126. "[A] transaction is Pareto optimal if it makes at least one person better off and no one worse off." Richard A. Posner, Utilitarianism, Economics, and Legal Theory, 8 J. Legal STuD. 103, 114 (1979).

127. There are many plausible responses to this question, and many alternative theories of contract enforcement; I mean here only to adumbrate some arguments that might be mustered in favor of the seemingly ludicrous no-contracts/no-marriage regime.

128. Cf. Examining the Work of State Courts, National Center for State Courts, http:/www.ncsconline.org/D_Research/csp/2007B_files/civil.pdf (2007) (reporting that contracts cases have increased sharply and that " $[\mathrm{m}]$ any states are struggling to clear their civil caseloads, possibly as a result of ... tightening resources").

129. See Emens, Intimate Discrimination, supra note 56, at 1384 (quoting exchange with Ellickson and explaining context). 


\section{Obligations for All: Conduct over Consent}

In a world without marriage or contract, would intimate partners necessarily have no legal obligations to one another? That is one way to imagine the regime I have been discussing, a regime we might call the "NoContract-No-Marriage" world.

Another way to picture our No-Contract-No-Marriage world is as one that lacks only those obligations based specifically on consent-consent to marriage or consent to contract. In the United States, marriage, like contract, typically relies upon a crucial moment of intent: the spoken "I do." ${ }^{\prime 30}$ But the state need not require an isolated moment of explicit intention before assigning obligations to parties. Indeed, most of our law operates without any such requirement; think of tort law, criminal law, and administrative law. A regime without consent-based obligations between intimate partners could still involve legal obligations. The regulatory apparatus would merely impose them in other ways, or on some other principle besides consent. Such obligations are ascriptive-they are ascribed rather than affirmatively undertaken.

A quasi-legal text gives us a jumping-off point for imagining such obligations-though it does so assuming a backdrop of both marriage and contract. This text is the American Law Institute ("ALI") Principles of the Law of Family Dissolution. ${ }^{131}$ The ALI suggests imposing support obligations between intimate partners after just two to three years of cohabitation. ${ }^{132}$ If two people live together as a couple for this period, then (subject to various exceptions and variations) the ALI urges that states treat them the same as married partners in terms of property distribution and alimony upon divorce. ${ }^{133}$ Note that the ALI's domestic partnership regime is not the same as common law marriage because it concerns only those obligations arising after, not during, the relationship, and concerns only obligations between partners, without assigning any obligations to the state or other third parties.

130. I say "typically" because eleven states and the District of Columbia still allow the formation of new common law marriages. See UTAH CodE ANN. 30-1-4.5 (2008); TEx. FAM. CODE ANN. $\$ 2.401$ (2007) (calling it "informal marriage'); Coleman v. United States, 948 A.2d 534, 544 (D.C. 2008); In re Marriage of Martin, 681 N.W.2d 612, 617 (Iowa 2004); Snetsinger v. Montana University System, 104 P.3d 445, 451 (Mont. 2004); DeMelo v. Zompa, 844 A.2d 174,177 (R.I. 2004); Standefer v. Standefer, 26 P.3d 104, 107 (Okla. 2001); In the Matter of the Petition of Lola Pace, 989 P.2d 297, 297 (Kan. 1999); People v. Lucero, 747 P.2d 660, 663 (Colo. 1987); Tarnowski v. Lieberman, 560 S.E.2d 438, 440 (S.C. Ct. App. 2002); Walker v. Walker, 567 So.2d 869, 869 (Ala. Civ. App. 1990); see also N.H. Rev. StAT. ANN. $\$ 457: 39$ (2009) (recognizing common law marriages only after the death of one partner).

131. Amer. L. Inst., Principles of the Law of Family Dissolution: Analysis and Recommendations (2002) [hereinafter PRINCIPLES].

132. Id. $\$ 6.03$, cmt. d.

133. See id. $\S 6.03 \mathrm{cmt}$. b. 
Domestic partnership under the ALI is based on behavior and reliance, rather than on the contractual moment of intent. ${ }^{134}$ As presented in the Principles, however, the ALI regime does incorporate ideas of contractual intent in two main ways. First, the ALI proposes the domestic partnership regime as a set of default rules, which the parties can avoid by expressly indicating their intent either to not assume such obligations or to assume other obligations. Second, the ALI envisions the domestic partnership regime as a supplement to a marital regime, so the contract-like moment of promising (to marry) is also recognized under the actual ALI regime.

A small revision to the ALI regime yields yet another possibility: our imagined No-Contract-No-Marriage regime could abandon the assumed background of our consent regimes. In its wake, picture the ALI's ascriptive domestic partnership regime, but without marriage of the "I do" variety or contracts between intimates. This revised ALI regime draws on our reimagined Virginia statute to envision a truly different regulatory universe.

The reasons discussed earlier for (hypothetically) questioning the advisability of enforcing contracts between intimates-bounded rationality, protection of a weaker party, inadequate benefits to the parties, costs to the state-could also support obligations assumed through behavior and reliance rather than affirmative consent. That is, ascribing obligations could be appealing because people in intimate relationships may be boundedly rational and thus unrealistic about what the future holds and what they might need to do to protect themselves; because women, more than men, may become economically dependent through their intimate relationships; because welldesigned background rules (if we assume or strive for them to be so) may be welfare-promoting in ways that such parties' contracts might not be; and because the end of such relationships may lead some (most often women and children) to be dependent on the state. ${ }^{135}$ Thus, the same rationales that could support the refusal to recognize romantic parties' spoken commitments to one another could nonetheless be invoked to recognize some obligations-those obligations created through behavior rather than words. Once again, we see that seemingly outlandish proposals warrant consideration because they intersect with the values of existing institutions.

134. The ALI Principles approach has been the subject of extensive debate, which I do not even attempt to catalogue in this short Essay. By way of example, see Ira Mark Ellman, "Contract Thinking" Was Marvin's Fatal Flaw, 76 Notre Dame L. Rev. 1365 (2001); Nancy D. Polikoff, Making Marriage Matter Less: The ALI Domestic Partner Principles Are One Step in the Right Direction, 2004 U. CHI. Legal F. 353 (2004); Elizabeth S. Scott, Marriage, Cohabitation, and Collective Responsibility for Dependency, 2004 U. CHI. LEGAL F. 225 (2004).

135. See, e.g., Theresa Glennon, Still Partners? Examining the Consequences of Postdissolution Parenting, 41 FAM. L.Q. 105, 110-11 (2007) ("Current approaches to the financial dissolution of marriages leave women and children in their care experiencing, on average, a thirty percent decline in their standard of living after a divorce."); Linda C. McClain, "Irresponsible" Reproduction, 47 Hastings L.J. 339, 355-56 (1996) (noting that "divorce or marital separation is the most common precipitating factor which leads women to seek [AFDC] benefits"). 


\section{A Range of Alternatives: From Consent to Conduct and Back}

This is not to say that an ascriptive regime of this sort is actually preferable to consent-based regimes such as contract or marriage. But as part of this exploratory exercise, we do well to consider the range of alternatives. Table I thus presents a summary of several of the imaginative possibilities inspired by the Virginia mini-DOMA and the ALI Principles regimes together.

Table I: Countermarriage Possibilities from No-Contract and Ascriptive Regimes

\begin{tabular}{|c|c|c|}
\hline & $\begin{array}{l}\text { Consent sufficient to create } \\
\text { obligations }\end{array}$ & $\begin{array}{l}\text { Consent not sufficient to } \\
\text { create obligations }\end{array}$ \\
\hline $\begin{array}{l}\text { Behavior } \\
\text { sufficient to } \\
\text { create } \\
\text { objections }\end{array}$ & $\begin{array}{l}\text { I: } \text { ALI regime } \\
\text { - marriage and contract } \\
\text { alongside ascriptive } \\
\text { domestic partnership } \\
\text { regime }\end{array}$ & $\begin{array}{l}\text { II: No-Contract-No- } \\
\text { Marriage world plus revised } \\
\text { ALI regime } \\
\text { - no marriage } \\
\text { - no contract } \\
\text { - ascriptive obligations }\end{array}$ \\
\hline $\begin{array}{l}\text { Behavior not } \\
\text { sufficient to } \\
\text { create } \\
\text { objections }\end{array}$ & $\begin{array}{l}\text { III: Current regime (for those } \\
\text { eligible for marriage) } \\
\text { - marriage } \\
\text { - contractual alternatives } \\
\text { - few ascriptive obligations }\end{array}$ & $\begin{array}{l}\text { IV: No-Contract-No- } \\
\text { Marriage world } \\
\text { - no marriage } \\
\text { - no contractual alternatives } \\
\text { - no ascriptive obligations }\end{array}$ \\
\hline
\end{tabular}

The table brings together the different regimes outlined in this Part. It shows us the version that is closest to our current regime (Box III) for those people eligible for marriage. This includes the availability of both marriage and contract, ${ }^{136}$ but few ascriptive obligations in the absence of consent.

The table also shows us three alternative worlds. The actual ALI regime (Box I) retains marriage and contract and adds some ascriptive obligations for those who do not create consent-based obligations but behave in ways that trigger the ALI regime. The aim here, as the ALI indicates, is to protect vulnerable parties in serious but not formalized relationships by creating a regime for sorting out the breakdown of their relationships. ${ }^{137}$ The regime in this box could also go beyond what the ALI envisions and entail a broader range of obligations-including obligations between partners while still together. Such a regime might be compared to the common-law marriage

136. It might be more accurate to say "either marriage or contract," as the ability to marry and contract about the inner workings of marriage (as opposed to the terms of dissolution) is relatively limited.

137. Marvin doctrine is sometimes used to this effect, even without an explicit oral agreement. See Ellman, supra note 134, at 1365 (summarizing Marvin doctrine). 
regimes still extant in several states, although such regimes typically require some form of consent. ${ }^{138}$

The No-Contract-No-Marriage world (Box IV) repudiates obligations between intimate partners altogether. Here there are neither consent-based obligations (marriage or contract) nor ascriptive obligations (like those the ALI proposes). This is the world we envisioned by universalizing the broadest reading of Virginia's mini-DOMA. Intimacy in this world is deemed incompatible with legal commitments.

Finally, the regime that is perhaps furthest from our own (Box II) brings our variation on the ascriptive ALI Principles together with the No-ContractNo-Marriage regime we derived from Virginia's mini-DOMA. This regime ascribes obligations based on behavior, and does not enforce obligations undertaken by consent-whether piecemeal through contract or wholesale through marriage. This regime moves farthest away from our usual respect for consent through contractual or marital commitment.

Across our legal and literary sources, we have seen countermarriage regimes that depart from our current regimes along many axes, including the conditions of entry (whether based on consent or behavior), the participants (who gets in and with what structure), the benefits and burdens (from financial obligations to a reprieve from death), the dimension of time (in terms of continuity and permanence), the conditions of exit (how it is effected and whether any rights persist), and the form of the legal rule (from criminal prohibition to default presumption to forced choosing). These regimes are not proposals for improvements on our current regime. They are exercises to push our minds through a range of alternatives, and to lead us to see the kinds of possibilities that might exist.

\section{CONCLUSION: OF LAW, LITERATURE, AND INNOVATION}

Marriage is the triumph of imagination over intelligence.

Second marriage is the triumph of hope over experience. ${ }^{139}$

These lines, often mistakenly attributed to Oscar Wilde, present ordinary marriage as an imaginative endeavor. It may be so, at least for some. And it is

138. On common-law marriage, see note 130

139. This popular phrase has variously been attributed to diverse sources, including Oscar Wilde. The attribution appears to be apocryphal, and the phrase a paraphrase and amalgamation of separate witticisms by Samuel Johnson and H.L. Mencken. See Boswell, I Life of SamuEL Johnson 376 (Sir Isaac Pitman \& Sons 1907) (entry for 1770) ("A gentleman who had been very unhappy in marriage, married immediately after his wife died: Johnson said it was the triumph of hope over experience."); H.L. Mencken \& George Jean Nathan, Heliogabalus 131 (Knopf 1920) ("She was complaining that love was beyond her comprehension-that it was ineffable, indescribable, transcendental. 'Love,' $I$ replied, with droll perspicacity, 'Love,' I replied, 'is the triumph of imagination over intelligence."'). 
certainly possible that little should change in our current marriage regime. ${ }^{140}$ As I noted at the start, my aim has not been to argue for one or another countermarriage regime, but to excavate possibilities from some unlikely sources. I thus conclude with a few reflections on these sources, and on the relationships among law, literature, and innovation.

Various justifications may be offered for the status quo. For some traditions and thinkers, the way things are is the way they should be"Whatever is, is right." 141 Burke famously extolled the virtues of tradition as the accumulated wisdom of the centuries. ${ }^{142}$ More recently, there's the joke about the (old school) Chicago economist:

A Chicago economist and a friend were walking along the street when they spotted a $\$ 20$ bill. The economist kept walking. The friend turned to him and asked, "Aren't you going to pick that up?" "Of course not," said the economist. "It's fake. If there were a real $\$ 20$ bill on the sidewalk, someone would have picked it up already."

The joke plays off classical economic principles, which suggest that the current state of affairs cannot be improved upon, because the market has already perfected it. ${ }^{144}$ The efficient markets hypothesis, for instance, posits that prices accurately reflect all available information, and indeed instantly incorporate any information that becomes newly available. Similarly, in the joke, money could never be available for free.

The joke may be read as a fable about how certain assumptions about economics can impoverish our sense of what is possible. The efficient markets hypothesis and its ilk have of course been criticized from within economics, and not just by behavioral economics. ${ }^{145}$ And various forms of economic thinking have been the source of highly innovative and provocative ideas. ${ }^{146}$ But the pervasive use of certain concepts from economics, stripped of context or crucial critique, may constrain our exploration of alternatives. For example, the so-called Coase theorem, which is widely taught in law schools, has been frequently mischaracterized as a theory of how legal rules might not matter to

140. It is possible, that is, that little should change other than who can participate, though I do not present the case for that position here.

141. Alexander Pope, Essay on Man (1734) (11. 293-94).

142. See, e.g., Edmund Burke, Reflections on the Revolution in France, in ThE PORTABLE EDMUND BURKE 456 (Isaac Kramnick ed., 1999).

143. See Laughter Soothes the Wounded Heart, No Joke: Animals Laugh, Too, $\mathrm{http}: / /$ www.flatrock.org.nz/topics/humour/no joke.htm (offering slightly different wording).

144. See also Aha Jokes, Economist Jokes, http://www.ahajokes.com/econ002.html ("Q: How many Chicago School economists does it take to change a light bulb? A: None. If the light bulb needed changing the market would have already done it.").

145. See, e.g., Ronald Coase, The Problem of Social Cost, 3 J.L. \& Econ. 1 (1960); see also, e.g., BEhavioral Law AND Economics (Cass R. Sunstein ed., 2000).

146. For some family-law related examples, see, for example, GARY S. BECKER, A Treatise on The Family 81-104 (1991); Elisabeth M. Landes \& Richard A. Posner, The Economics of the Baby Shortage, 7 J. LEGAL STUD. 323 (1978). 
outcomes, even though Coase actually meant to highlight the importance of transaction costs, not to posit their non-existence. ${ }^{147}$ Why the slippage exists is an interesting question; there are apparently disciplinary and context-specific reasons for it, ${ }^{148}$ but perhaps there is also something alluring about the idea that things are as they should be, that private parties will work them out unaided by law. ${ }^{149}$ Regardless, the slippage surrounding Coase is one example of how watered-down principles of classical economics - at least in legal educationmay hinder legal thinkers' appreciation of law's imaginative possibilities, of the potential benefits, as well as the costs, of innovation.

Research in fields ranging from social psychology (on system justification and status quo bias) to organizational theory (for example, on the so-called dark side of organizations) has documented the ways we become stuck in the present configuration of things. ${ }^{150}$ What allows us to think beyond the ruts we create for ourselves, to imagine and examine other possibilities?

In their different ways, both law and literature are realms of the imagination, both mechanisms for innovation. Both urge us to expand our thinking beyond the status quo. Literature is obviously a realm of the imagination. Scholars have already written about the political possibilities of the literary imagination, for instance, in helping to facilitate empathy with diverse others. ${ }^{151}$ But literature has been underutilized as a source of legal innovation.

147. See Coase, supra note 145; Robert C. Ellickson, The Case for Coase and Against "Coaseanism", 99 YALE L.J. 611 1, 614 (1989) ("In a retrospective essay in his recent book, Coase writes: "The world of zero transaction costs has often been described as a Coasian world. Nothing could be further from the truth. It is the world of modern economic theory, one which I was hoping to persuade economists to leave."') (citing Ronald CoASE, ThE FIRM, THE MARKET, AND THE LAW 174 (1988)); West, supra note 9, at 1190 (1996) ("Virtually all law students, for example, at virtually all law schools, will receive, most likely in the very first semester of law school, some exposure to the logic and impact of the Coase theorem . . . .); $c f$. Michael R. Butler \& Robert F. Garnett, Teaching the Coase Theorem: Are We Getting It Right?, 31 AtLantiC ECON. J. 133 (2003) (concluding from a survey of microeconomic textbooks that these texts frequently mischaracterize Coase in this way).

148. See, e.g., Butler \& Gamett, supra note 147 (explaining the development of this misapprehension).

149. Cf. John J. Donohue III, Commentary, Opting for the British Rule, or If Posner and Shavell Can't Remember the Coase Theorem, Who Will?, 104 HARv. L. REv. 1093, 1115 (1991) ("The human mind finds it far easier to make the best out of the current state of the world than it does trying to conceive all of the ways in which the state of the world itself can be altered.").

150. On the former, see Gary Blasi \& John T. Jost, System Justification Theory and Research: Implications for Law, Legal Advocacy, and Social Justice, 94 CALIF. L. REV. 1119 , 1119 (2006) (discussing, as the focus of System Justification Theory, "the motive to defend and justify the social status quo, even among those who are seemingly most disadvantaged by it"); Russell Korobkin, The Endowment Effect and Legal Analysis, 97 Nw. U. L. REv. 1227, 1228-29 (2003) (explaining "status quo bias" as the tendency of "individuals . . to prefer the present state of the world to alternative states, all other things being equal"); see also MARTHA MINOw, Making All the Difference (1991). On the latter, see Diane Vaughan, The Dark Side of Organizations: Mistake, Misconduct, and Disaster, 25 ANN. Rev. Soc. 271 (1999); see also Kenneth A. Bamberger, Regulation as Delegation: Private Firms, Decisionmaking, and Accountability in the Administrative State, 56 DuKE L.J. 377, 417-20 (2006).

151. See, e.g., Martha Nussbaum, Narratives of Hierarchy: Loving v. Virginia and the 
Literature allows us to imagine entirely new regulatory worlds because fictional worlds are also rule-bound. Literature, though it need not play by reality's rules, is not a free-for-all. Literary texts create fictional worlds with internal rules that dictate what is possible within that world. It is for this reason that we can say something is "unrealistic" or "would never happen" within a work of, say, science fiction, whose frame is unrealistic; what we mean is that the particular event violates the rules of that fictional world. The need for a nuanced rendering of a rule-bound universe--but where the usual nonfiction rules need not apply-makes fiction a space for testing out regulatory possibilities.

Law seems a less likely candidate for an imaginative realm. And yet law can force us out of the status quo as well. It can force us to change practices, sometimes on the level of the minute details of our lives. Think of sexual harassment law, which changed everyday workplace interactions in ways inconceivable before its instantiation. ${ }^{152}$ Law can work against status quo bias; for better or worse, it can force change into contexts that social pressures cannot reach. In this way, law and literature have more in common than they appear, as both invite innovation by spurring us to move beyond our conventional choices into uncharted territory. Literature generally does this by permission and imaginative license; law, in contrast, may do so by mandate.

None of these considerations show that things should change. Sometimes the way things are is, indeed, the way things should be. But as Justice Holmes famously wrote, "[i]t is revolting to have no better reason for a rule of law than that so it was laid down in the time of Henry IV." "153 As scholars and students, we should at least consider the range of alternatives to the present state of things before reaching a conclusion about the normative merits or demerits of keepings things as they are. In this possibly brief historical window of societal rumination on the question whither marriage, we should look to whatever sources we can find to open our minds to every imaginative possibility. We should therefore look to both law and literature.

Literary Imagination, 17 QUINNIPIAC L. REv. 337 (1997).

152. See, e.g., Directions in Sexual Harassment Law (Catharine A. Mackinnon \& Reva B. Siegel eds., 2003).

153. Oliver Wendell Holmes, The Path of Law, 10 Harv. L. Rev. 457, 469 (1897). Holmes continued, "[i]t is still more revolting if the grounds upon which it was laid down have vanished long since, and the rule simply persists from blind imitation of the past." Id. 